\title{
Advanced analytical techniques for studying the morphology and chemistry of Proterozoic microfossils
} \\ KEYRON HICKMAN-LEWIS ${ }^{3,5,6} \&$ MARTIN D. BRASIER ${ }^{3 \dagger}$ \\ ${ }^{1}$ Centre for Microscopy Characterisation and Analysis, and Australian Research \\ Council Centre of Excellence for Core to Crust Fluid Systems, The University of \\ Western Australia, 35 Stirling Highway, Perth, WA 6009, Australia \\ ${ }^{2}$ School of Earth Sciences, University of Bristol, Life Sciences Building, \\ 24 Tyndall Avenue, Bristol BS8 1TQ, UK \\ ${ }^{3}$ Department of Earth Sciences, University of Oxford, South Parks Road, \\ Oxford OX1 3AN, UK \\ ${ }^{4}$ School of Earth, Atmospheric and Environmental Sciences, University of \\ Manchester, Manchester M13 9PL, UK \\ ${ }^{5}$ St Edmund Hall, Queens Lane, Oxford OXI 4AR, UK \\ ${ }^{6}$ Present address: Homestead, 19 Sunnybank Road, Blackwood, Gwent, NP12 1HT, UK \\ *Correspondence: David.Wacey@uwa.edu.au
}

DAVID WACEY ${ }^{1,2 *}$, LEILA BATTISON ${ }^{3}$, RUSSELL J. GARWOOD ${ }^{4}$,

\begin{abstract}
This paper outlines the suite of advanced multi-scalar techniques currently available in the toolkit of the modern Proterozoic palaeobiologist. These include non-intrusive and nondestructive optical, laser and X-ray techniques, plus more destructive ion beam and electron beam methods. Together, these provide morphological, mineralogical and biochemical data at flexible spatial scales from that of an individual atom to the largest Proterozoic microfossils. An overview is given of each technique and a case study from the exceptionally well-preserved Torridonian biota of NW Scotland is presented. This microfossil assemblage was first recognized over a century ago, but its great diversity and evolutionary importance has only recently come to light, due in no small part to the research efforts of Martin Brasier.
\end{abstract}

Modern palaeobiology primarily exists to discover, describe and decode the ancient biosphere, and to understand the course of global evolutionary change. Stemming from its roots in Victorian natural history, palaeobiology has made good use of technological advances to shed light on new discoveries (see Sutton et al. 2014; Wacey 2014 and references cited therein) and to reveal previously unimagined details in historical material (Brasier et al. 2015). As with any modern field of science, palaeobiological research must continually look forwards to the next potential discovery, utilizing all the available tools and techniques.

Historically, major discoveries have predominantly dated from the Phanerozoic as a result of the relatively well-preserved and easily recoverable fossils of the macroscopic organisms alive during this time. In the search for life's origins and early record, attention has inevitably turned to the more poorly understood Proterozoic and Archaean fossil records. The evolutionary history of these expanses of time is much less well established because there is a shortage of exposed rock of the appropriate age, a relative paucity of fossil material and limitations in extracting the relevant information. Fossils from these times are typically microscopic, enigmatic and poorly preserved, although a number of exceptionally preserved deposits have come to characterize the Proterozoic fossil record (e.g. the Torridonian biota, Strother et al. 2011; the Doushantuo biota, Yin \& Li 1978). In both 'traditional' and 'exceptional' examples of preservation, our

${ }^{\dagger}$ Deceased 16 December 2014.

From: Brasier, A. T., McIlroy, D. \& McLoughlin, N. (eds) Earth System Evolution and Early Life: a Celebration of the Work of Martin Brasier. Geological Society, London, Special Publications, 448, http://doi.org/10.1144/SP448.4

(C) 2016 The Author(s). Published by The Geological Society of London. All rights reserved.

For permissions: http://www.geolsoc.org.uk/permissions. Publishing disclaimer: www.geolsoc.org.uk/pub_ethics 


\section{WACEY ET AL.}

understanding is still limited by the observational and analytical techniques used to characterize these important specimens.

The approaches traditionally used to study early fossil material are essentially borrowed and adapted from the methods used in the study of Palaeozoic fossils and are best suited to hard-bodied macroscopic fossils or compressed organic material extracted by acid maceration. However, as our understanding of Precambrian environments has fundamentally improved, it has become clear that entirely different preservational styles are possible, some of which require novel analytical approaches. Although many Proterozoic carbonaceous fossils can still be found compressed within shales (Javaux et al. 2004; Agic et al. 2015) and can be extracted for study by palynological acid maceration techniques, microfossil material can also be hosted in a variety of other media, including chert (e.g. Barghoorn \& Tyler 1965), pyrite (e.g. Rasmussen 2000), authigenic aluminosilicates (e.g. Wacey et al. 2014) and cryptocrystalline phosphate (e.g. Strother et al. 2011). These alternative preservational styles originate from the biogeochemical conditions that prevailed in specific environments or across specific periods of time. They are able to exceptionally preserve microfossils of a wide range of affinities in their original spatial context, often in three dimensions, reflecting a broad spectrum of taphonomic decay. In these cellular Lagerstätte, challenges are posed by the small scale, enigmatic nature and relative scarcity of Proterozoic fossils, as well as by their complex taphonomic and metamorphic histories. Thus a thorough understanding of Proterozoic and Archaean life necessarily calls for state of the art, high spatial resolution and holistic imaging and analysis techniques.

An increasing number of researchers are now making use of such techniques to study both Proterozoic and Archaean material, revealing unprecedented levels of detail and allowing the reconstruction of the complex Precambrian biosphere. It is still common, however, for these different approaches to be attempted separately, often by different individual research groups, which can partially preclude the synthesis of information and an overall understanding of local, regional or even global palaeoecologies. Here we present a holistic methodology for studying Proterozoic fossil deposits with a consideration of their unique preservational styles and histories. A set of complementary microanalysis techniques has already been presented with respect to Archaean material (Wacey 2014). However, with the expansion of the biosphere (Knoll 1994), the evolution of eukaryotic cells (Knoll et al. 2006) and the advent of various metabolic pathways and trophic tiering (Knoll 2015), the Proterozoic fossil record is more complex and - as a result of its younger age (c. 2500$540 \mathrm{Ma}$ ) - arguably better preserved. Thus a greater potential wealth of information might be gleaned from such deposits, necessitating their study on a variety of spatial scales, as well as assessing both their morphology and chemistry.

The following sections detail, in a logical order for practical investigation, multiple approaches to examining a Proterozoic microfossil assemblage, including the following: 'traditional' field study and optical microscopy; X-ray based techniques, including X-ray computed tomography (CT) and $\mathrm{X}$-ray spectroscopy; laser-based techniques, including Raman spectroscopy and confocal laser scanning microscopy (CLSM); infrared spectroscopy; electron-based techniques, including scanning electron microscopy (SEM) and transmission electron microscopy (TEM); and ion-based techniques, including focused ion beam (FIB) milling and secondary ion mass spectrometry (SIMS). A combination of several of these techniques when investigating a single fossil deposit provides the best opportunity to fully reveal the palaeocology of the Proterozoic biosphere. An example of their application to the microfossiliferous rocks of the 12001000 Ma Torridonian Supergroup of NW Scotland is presented as a demonstrative case study.

\section{Standard palaeobiological techniques}

\section{Field study and optical microscopy}

A crucial starting point for any palaeobiological investigation remains a comprehensive field study and the preparation of candidate material for optical microscopy. As a preliminary investigation, this can provide an important palaeoenvironmental context and enable the quantification of the richness, morphology and spatial distribution of fossils, plus the depositional setting and taphonomic history of the fossil deposit.

A detailed sedimentological and stratigraphic study should initially be made of the fossiliferous rocks, and the rocks associated with them, to allow accurate palaeoenvironmental, metamorphic and tectonic interpretations. Such a study will provide regional, local and fine-scale information pertaining to the location, type and energy of the environment of deposition, as well as any subsequent chemical or structural changes that may have taken place since lithification. Fine-scale field observations will also allow the identification of candidate fossiliferous material. This may be related to specific preservational mineralogies, such as cherts (e.g. the c. $1900 \mathrm{Ma}$ Gunflint Formation; Barghoorn \& Tyler 1965) or phosphates (e.g. the $c$. 600 Ma Doushantuo Formation; She et al. 2013) or be found in association with macroscopic fossil structures, including siliceous 


\section{ANALYTICAL TECHNIQUES FOR PROTEROZOIC MICROFOSSILS}

and phosphatic stromatolites (e.g. the c. $1900 \mathrm{Ma}$ Belcher Supergroup; Hofmann 1976) and microbially induced sedimentary structures (e.g. the $c$. 1000 Ma Diabaig Formation; Callow et al. 2011). The collection and documentation of candidate material should be methodical and include global positioning system localities, orientation data and specific relationships with larger scale structures.

Polished, uncovered (which are more useful than covered for subsequent techniques) petrographic thin sections can be prepared from the collected samples for analysis using optical microscopy. Ideally, thin sections should be prepared both perpendicular and parallel to the bedding direction to capture the full spatial distribution of microscopic fossils. Although sections $30 \mu \mathrm{m}$ thick are required for mineral identification using crosspolarized light, the detection of fossil material may be facilitated by the use of sections up to $c .150 \mu \mathrm{m}$ thick, provided the encasing medium is sufficiently light-coloured and free of dark impurities. This increases the chances of capturing entire cellular material and the in situ relationships between different fossil taxa.

The primary purpose of optical microscopy is to locate and identify fossil material and to document its spatial distribution and relationship with non-biological minerals. For the majority of Proterozoic carbonaceous fossil deposits, examination and imaging at all magnifications up to $1000 \times$ are needed to provide a complete context. This can allow the observation of fine structural details up to $c .0 .2 \mu \mathrm{m}$ across, but note that oil immersion is required at the highest resolutions to increase clarity, which may be detrimental to some subsequent techniques. The position of fossil material can be identified and recorded for future reference using standard graticules, When fossil material is preserved with some degree of three dimensionality, focusing through the thickness of the slide can reveal its shape, organization and extent. A range of different photomicrography suites is now available for capturing images of such samples (e.g. Synchroscopy Auto-Montage, as demonstrated by Brasier et al. 2005). Many packages contain algorithms for stacking focused images from different depths within a section to produce a single, focused image, or for stitching together images of adjacent fields of view to produce a high-resolution 'map' of a thin section.

Using a variety of optical micrographic tools, the preliminary identification and quantification of fossil material may be carried out, larger scale spatial relationships determined and candidate fossils selected for further analysis. This work is vital for the initial study of a fossil deposit, but the intrinsic limitations of this approach preclude its use for finer scale analyses. Certain media may be unsuitable for investigation by optical microscopy. Dark-coloured material, or enclosing media with many impurities, for example, may mask fossil details and reduce their visibility, especially through thick sections. Larger microfossils may be cross-cut by the sectioning process, limiting interpretation. Another limitation is that the identification of the chemical constituents of samples is limited to that which can be determined by standard petrographic methods and may not be sufficient for fine-grained or finely crystalline material. As carbonaceous fossils are often dark coloured, optical analyses will only be able to resolve their surface shape and structure, with the fossils themselves masking any underlying ultrastructure or interior features. Thus more versatile high spatial resolution techniques are required for a better understanding of both fossil material and its preservational medium.

\section{Non-destructive moderate to high spatial resolution techniques}

Non-destructive techniques are classified here as techniques that can be applied to a standard geological thin section, rock chip or rock hand sample with minimal sample preparation and that do not consume or alter the specimen of interest during the analysis. Hence they can be applied to type specimens (including holotypes on loan from museums) and can be utilized as a precursor to more destructive techniques on newly discovered material.

$X$-ray computed tomography. X-ray CT maps the $\mathrm{X}$-ray attenuation within a rotating sample. Data are captured as a series of projections that can be reconstructed as two-dimensional (2D) slices and three-dimensional (3D) visualizations (see Kak \& Slaney 2001; Cnudde \& Boone 2013 for overviews). The X-ray attenuation is dictated by factors such as the elemental composition and density, hence X-ray CT can often detect variations in the style of fossil preservation and mineralization, as well as building up 3D models of entire specimens (Conroy \& Vannier 1984; Haubitz et al. 1988; Sutton et al. 2001). The high-resolution form of X-ray CT used for fossils is known as X-ray microtomography $(\mu \mathrm{CT})$ and has been utilized in palaeobiology for almost two decades (Rowe et al. 2001; Sutton 2008). It is routinely applied to Phanerozoic vertebrate and invertebrate fossils, ranging from echinoderms (Rahman \& Zamora 2009) to dinosaurs (Brasier et al. 2016) and from plants (Spencer et al. 2013) to arthropods (Garwood \& Sutton 2010). The study of microfossils using CT has become viable in recent years with the use of synchrotron-based systems in which more intense, monochromatic X-rays result in improved contrast and greater spatial resolution (Donoghue et al. 2006; Huldtgren et al. 2011). 


\section{WACEY ET AL.}

Recent years have also seen improvements in the spatial resolution of laboratory-based $\mu \mathrm{CT}$ and nano-CT systems where sub-micrometre resolutions are now possible (Hagadorn et al. 2006; Schiffbauer et al. 2012; Sutton et al. 2014).

Despite these technological advances, configuring the correct instrumental parameters for $\mu \mathrm{CT}$ scanning a given microfossil specimen is challenging and some specimens will not be suited to $\mu \mathrm{CT}$ techniques due to a lack of $\mathrm{X}$-ray attenuation contrast between the specimen and the matrix and/or the presence of X-ray opaque minerals. In general, $\mu \mathrm{CT}$ is applied to small rock chips. It is not suited to geological thin sections because of their highly anisotropic nature, although thin sections can be cut down to a more isotropic shape if allowed by the owner, or the fossils can be liberated using a micro-corer. Elsewhere in this volume, HickmanLewis et al. (2016) report several case studies of the $\mu \mathrm{CT}$ scanning of Precambrian microfossilbearing rocks using two laboratory-based CT scanners with spatial resolutions (minimum voxel sizes) of about 5 and $0.5 \mu \mathrm{m}$, respectively. They show that $\mu \mathrm{CT}$ can be a valuable tool to decode the 3D petrographic context of such biological material for example, by highlighting potential organic grains and laminations, fractures within the matrix, assemblages of detrital heavy minerals and the replacement of silica by carbonate rhombs (which are known to reduce the quality of microfossil preservation). Detecting individual microfossils using laboratory-based CT remains challenging unless the preservation window is particularly favourable (e.g. pyritized microfossils in a silica matrix; see Hickman-Lewis et al. 2016). The use of a synchrotron-based CT (or laboratory-based nano-CT) system can improve results by providing more intense $\mathrm{X}$-rays and improved spatial resolution, but this requires more specialist sample preparation (e.g. micro-coring) to obtain sub-millimetre pieces of fossiliferous rock, meaning that it can no longer be realistically classified as a non-destructive technique and can seldom be applied to holotype material.

$X$-ray spectroscopy. A logical extension to examining the morphology of microfossils using X-ray microtomography is to investigate their chemistry using X-ray spectroscopy. A range of X-ray techniques is available to characterize fossiliferous rocks, most performed on a synchrotron beamline (for overviews, see Fenter et al. 2002; Templeton \& Knowles 2009) and utilizing both hard X-rays (more penetrating with wavelengths of 1-20 $\AA$ and photon energies $>5-10 \mathrm{keV}$ ) and soft X-rays (less penetrating with wavelengths of 20-200 $\AA$ and photon energies $<5 \mathrm{keV}$ ). X-ray fluorescence mapping provides semi-quantitative element-specific maps over flexible spatial scales (micrometres to millimetres, e.g. Edwards et al. 2014). Near-edge $\mathrm{X}$-ray absorption fine structure and X-ray absorption near-edge structure spectrometry are techniques that use soft (low-energy) and hard (high-energy) $\mathrm{X}$-rays, respectively, to excite the core electrons in an element (Templeton \& Knowles 2009). The resulting spectra provide information on both the coordination chemistry and valence of the element of interest. Scanning transmission X-ray microscopy uses soft X-rays to obtain both spectral data and images of these spectral data (e.g. maps of the spatial distribution of specific elements, valence states or functional groups) at the nanometre scale, created by rastering samples through an X-ray beam at stepwise-increasing incident $\mathrm{X}$-ray energies to cover the absorption edges of the elements of interest (e.g. Lawrence et al. 2003). Although these types of analyses do not destroy the specimen, specialist sample preparation (e.g. micro-cored rock chips; doubly polished thin sections no more than c. $100 \mu \mathrm{m}$ thick) means that permission for holotype specimens to be analysed in this way is unlikely to be granted. Beam damage can also affect subsequent chemical analyses.

In terms of Proterozoic microfossils, much of the interest in X-ray spectroscopy surrounds the chemical bonding of carbon. The energy resolution of X-ray absorption fine structure/X-ray absorption near-edge structure is excellent $(c .0 .1 \mathrm{eV})$, so closely spaced peaks can be resolved. Hence carbon bound in aromatic groups, aliphatic groups, ketones, peptides, carbonyls, carboxyls and carbonate can all be distinguished from one another (Bernard et al. 2007). Such spectra may help to characterize cellular v. extracellular organic components and the interfering signals from carbonate minerals can be subtracted. De Gregorio et al. (2009) applied this methodology to powders of organic material from the 1878 Ma Gunflint Formation and showed that polyaromatic carbon, carboxyl and phenol groups had all been preserved in this ancient kerogen. Similarly, the bonding characteristics of other elements common in organic material (e.g. S, N, P, O) may help to determine whether they are present as organic or inorganic forms in ancient fossiliferous rocks. For example, Lemelle et al. (2008) used X-ray fluorescence to quantify the amounts of sulphur within the cell walls of coccoid microfossils from the $c$. 750 Ma Draken Formation, Svalbard before using $\mathrm{X}$-ray absorption near-edge structure techniques to determine the speciation of sulphur. They showed that the sulphur was a reduced organic form and was most likely present as a thiophene-like compound.

Confocal laser scanning microscopy. The technique of CLSM provides high spatial resolution morphological data $(<100 \mathrm{~nm}$ is possible) allowing 


\section{ANALYTICAL TECHNIQUES FOR PROTEROZOIC MICROFOSSILS}

the visualization of microfossils in three dimensions (for overviews, see Halbhuber \& Konig 2003; Sutton et al. 2014). Under ideal conditions data collection from standard polished or unpolished geological thin sections is rapid and CLSM is able to resolve tiny morphological features that may be unclear or hidden when viewed under light microscopy, as well as giving a true $3 \mathrm{D}$ perspective to the distribution of microfossils (Schopf et al. 2006; Cavalazzi et al. 2011). However, natural samples are rarely ideal for the application of this technique. CLSM relies on the fact that organic material auto-fluoresces when excited by a laser of a specific wavelength. The system can accurately focus and scan at different depths within a microfossil specimen and can exclude fluorescence outside the plane of focus; 3D images are then built up combining the data acquired from successive planes of focus (see Amos \& White 2003). Hence anything that interferes with the transmission or detection of this signal severely degrades the quality of the final images obtained. For example, specimens situated a long way below the surface of a thin section or with thick opaque walls will not provide sharp CLSM images. Similarly, a specimen surrounded by plentiful fluorescing organic detritus, or one that is embedded in a mineral that internally reflects the fluorescence signal, may be problematic. The maturity of the organic material also affects the quality of the data, with the auto-fluorescence signal dissipating as the organic material becomes more geochemically mature and loses more of its heteroatoms (i.e. evolves towards the structure of graphite). Hence CLSM is of greatest use when applied to thin-walled organic microfossils preserved in silica (and, to a lesser extent, phosphate) and housed in rocks of low metamorphic grade. In these cases significant insights into the 3D morphology and taphonomic preservation of Proterozoic microfossils may be obtained. For example, in the Neoproterozoic Buxa Formation, CLSM was able to demonstrate the 3D organization of groups of filamentous microfossils (Schopf et al. 2008). In the $850 \mathrm{Ma}$ Bitter Springs Formation and the $650 \mathrm{Ma}$ Chichkan Formation, notches, tears, grooves and surface ornamentation were all detected in microfossils using CLSM (Schopf et al. 2006), whereas in the c. $580 \mathrm{Ma}$ Doushantuo Formation CLSM revealed parts of fibrous tissues and cell walls within fossil alga that were not visible by any other means (Chi et al. 2006).

Laser Raman microspectroscopy and imagery. Raman spectroscopy is a versatile, non-intrusive and non-destructive in situ technique. It can be used to identify the mineralogy of microfossils and their host rocks and is particularly sensitive to the molecular structure and geochemical maturity of carbonaceous phases such as kerogen - the prime constituent of organic-walled microfossils (for details, see Beyssac et al. 2002; Fries \& Steele 2011). In addition, when used in the confocal imaging mode, Raman spectroscopy can provide $2 \mathrm{D}$ and $3 \mathrm{D}$ chemical and structural maps of microfossils at moderate spatial resolution (potentially $<1 \mu \mathrm{m}$ ). Raman spectroscopy can be applied to rock chips and standard uncovered geological thin sections. Data are acquired via laser excitation of the chemical bonds within the sample. This excitation produces characteristic spectra depending on the minerals and compounds present. Maps can be constructed of the spatial distribution of various spectral parameters, including the intensity of a given peak (also sometimes referred to as a band) or the ratios of two given peaks.

For the field of Proterozoic palaeobiology, the peaks of interest are often associated with carbon. In perfectly crystalline graphite, a single firstorder peak occurs at $1582 \mathrm{~cm}^{-1}$, attributed to stretching of the $\mathrm{C}-\mathrm{C}$ bonds in basal graphite planes (known as the $\mathrm{G}$ or graphite peak) (Jehlicka et al. 2003). Second-order peaks occur at c. 2695 and $2735 \mathrm{~cm}^{-1}$. Imperfectly crystallized graphitic carbons, including kerogens, have additional peaks at $c .1355 \mathrm{~cm}^{-1}$ (known as the D1 or disordered peak) and $c .1620 \mathrm{~cm}^{-1}$ (D2, occurring as a shoulder to the $\mathrm{G}$ peak) and a single broad second-order peak at c. $2700 \mathrm{~cm}^{-1}$. The specific position, width and relative intensities of these peaks vary depending on the degree of ordering of the carbon and these parameters have been characterized in carbon of varying metamorphic grade in an attempt to use Raman spectroscopy as an indicator of the antiquity of carbon in ancient rocks (Tice et al. 2004). This is by no means an exact science because the starting composition of organic material in different metamorphic terrains, both geographically and temporally, may differ. Putative carbonaceous microfossils should, however, exhibit very similar Raman spectral features to other carbonaceous material in the same rock specimen because both should have undergone the same maturation processes. Raman spectra cannot be used to unequivocally determine the biogenicity of an ancient carbonaceous object because similar spectra to those of biogenic kerogens are seen in laboratorysynthesized abiological disordered carbonaceous material (Pasteris \& Wopenka 2003). However, the co-occurrence of a kerogenous composition with features that optically resemble cellular material provides promising preliminary data regarding biogenicity that can be further tested using techniques with a higher spatial resolution.

As with CLSM, the highest quality data are obtained from specimens close to the surface of a thin section and it has been suggested that for viable 


\section{WACEY ET AL.}

3D maps of kerogen to be produced, the entire specimen of interest should be no more than 6-8 $\mu \mathrm{m}$ below the surface (Marshall \& Olcott Marshall 2013). The best data will come from specimens lying under translucent minerals such as quartz c. $1-5 \mu \mathrm{m}$ below the surface of a thin section; microfossils associated with phases that fluoresce strongly under the laser excitation beam may not provide usable spectra. Care must also be taken not to confuse the carbon signature of interest with that produced by (1) the polymer used to attach the thin section to the glass slide, (2) any coating that may have been applied to the section during previous analyses and (3) overlapping peaks in the vicinity of carbon peaks - of particular note here is the $1320 \mathrm{~cm}^{-1}$ peak of hematite (Marshall et al. 2011). The carbon spectrum can also be artificially modified by using too high a laser power or by analysing right at the surface of a thin section that has been polished (Fries \& Steele 2011). Both of these conditions should always be avoided. Raman spectroscopy can also be used to elucidate some structural information from the minerals that host putative microfossils. Several minerals produce Raman spectral peaks that vary in intensity depending on their crystallographic orientation relative to the incoming laser. This feature can be used, for example, to image the distribution of the crystallographic axes of quartz to see whether putative microfossil material occurs between grain boundaries, is enclosed by entire grains or occurs in cracks (Fries \& Steele 2011).

Examples of Raman spectroscopy applied to Proterozoic microfossils include a study by Fries \& Steele (2011), who mapped the carbon D to carbon $\mathrm{G}$ peak intensity ratio (an indicator of graphite domain size) to show micron-sized variations in the structure of kerogen within and around examples of Huroniospora from the $1878 \mathrm{Ma}$ Gunflint Formation. This potentially reflects initial heterogeneities in the biological material. Also within the Gunflint Formation, Wacey et al. (2013) used Raman spectroscopy to demonstrate that Gunflintia microfossils were dominantly carbonaceous in composition, but were preserved as pyrite in microenvironments where anoxia had allowed the formation of pyrite via the metabolic activity of sulphate-reducing bacteria. Raman spectroscopy has been used extensively by Schopf and coworkers to characterize Proterozoic microfossils (Schopf et al. 2005, 2008; Schopf \& Kudryavtsev 2005, 2009), culminating in the Raman index of preservation. This correlates the geochemical maturity of the kerogen, the fidelity of microfossil preservation, the $\mathrm{H}: \mathrm{C}$ and $\mathrm{N}: \mathrm{C}$ ratios of organic material and the metamorphic grade of the rocks. Examples have been reported from 22 chert units ranging in age from 2100 to $400 \mathrm{Ma}$ (Schopf et al. 2005).
Micro-Fourier transform infrared spectroscopy. Micro-Fourier transform infrared (FTIR) spectroscopy is a vibrational technique that provides complementary information to that obtained from organic material using Raman spectroscopy. In particular, it provides data pertaining to the functional groups attached to carbon chains and their bonding environment within organic material (Mayo et al. 2004; Dutta et al. 2013; Chen et al. 2015). Different peaks in an IR spectrum arise due to different vibrational behaviours in the bonds of groups such as $\mathrm{CH}_{2}, \mathrm{CH}_{3}, \mathrm{C}-\mathrm{N}, \mathrm{C}=\mathrm{O}$ and others. FTIR spectroscopy can be applied non-destructively, but requires doubly polished thin sections. The main drawback is currently the limited spatial resolution that can be obtained, with recent studies reporting only a c. $15 \mu \mathrm{m}^{2}$ spot size in the transmission mode $(\mathrm{Qu}$ et al. 2015). This is sufficient to characterize larger Proterozoic acritarchs in palynological extracts (Arouri et al. 1999; Marshall et al. 2005) and groups of smaller filamentous and coccoid microfossils (Igisu et al. 2009), but is insufficient to determine the difference between the wall chemistry and internal chemistry of most Proterozoic organisms. The spatial resolution problem may be circumvented by using a micro-FTIR system attached to a synchrotron beamline, where spot sizes of $<5 \mu \mathrm{m}$ have been achieved for some parts of the spectra (Bambery 2016). However, this may require more specialist, often extremely difficult, sample preparation (e.g. $<20 \mu \mathrm{m}$ thickness, unglued slice).

Of particular interest are data from extant microorganisms, which suggest that FTIR may provide domain-specific information, whereby specific components (e.g. lipids) of different domains of life (i.e. prokaryote, eukaryote and archaea) may have characteristic ratios of $\mathrm{CH}_{2}$ and $\mathrm{CH}_{3}$ groups in their IR spectra (Igisu et al. 2009, 2012). This has led to FTIR being used in Proterozoic assemblages in an attempt to decode the phylogenetic affinity of microfossils (Igisu et al. 2009, 2014). Igisu Q5 et al. (2009) analysed microfossils in their mineral matrix and thus concentrated on the $\mathrm{CH}_{x}(2500-$ $3100 \mathrm{~cm}^{-1}$ ) region of the spectrum. This type of research is very much in its infancy and a better understanding, both of the changes in $\mathrm{CH}_{2} / \mathrm{CH}_{3}$ during post-mortem alteration processes and of the spectral parameters of differentiated cells in multicellular organisms, is required for these data to become a robust domain-level signature. Insufficient data currently exist for comparisons of organic material from different terranes and of different metamorphic grades using this technique. Nevertheless, FTIR analyses from the $850 \mathrm{Ma}$ Bitter Springs Formation, Australia and the 1878 Ma Gunflint Formation, Canada suggest that organisms in these fossil assemblages belong to Bacteria rather than Archaea or Eukarya (Igisu et al. 2009). Likewise, 


\section{ANALYTICAL TECHNIQUES FOR PROTEROZOIC MICROFOSSILS}

combined FTIR and Raman data from the $1485 \mathrm{Ma}$ Wumishan Formation, China (Qu et al. 2015) suggested that the organic material was derived from prokaryote cyanobacteria and was characterized by a homogenous and low $\mathrm{CH}_{3} / \mathrm{CH}_{2}$ ratio. FTIR data from acritarchs from the $c$. 575 Ma Tanana Formation, Australia suggest that Tanarium are probably eukaryotic micro-algae, but Leiosphaeridia may be Bacteria (Igisu et al. 2009, based on data presented in Marshall et al. 2005).

\section{Destructive high spatial resolution techniques}

Focused ion beam milling and scanning electron microscopy. The technique of SEM has traditionally been of limited use in characterizing Proterozoic microfossils in geological thin sections because the majority of microfossils are embedded within the thin section and below the reach of this surfacebased technique. SEM has, however, provided high spatial resolution morphological data from the surfaces of individual microfossils in acid-etched rocks or those extracted from their host rock using acid maceration. This has revealed, for example, delicate wall ultrastructures that could not be resolved under the light microscope (Javaux et al. 2004; Moczydlowska \& Willman 2009; Agic et al. 2015).

The use of SEM in Precambrian palaeobiology has been reinvigorated by a new generation of dualbeam instruments where the user has access to both an FIB and an electron beam (for overview, see Young \& Moore 2005). A highly focused beam of heavy ions (usually $\mathrm{Ga}^{+}$) can be used to sputter ions from the sample surface, essentially cutting into the sample with very high (nano-scale) precision (for details, see Wirth 2009). The electron beam can be used to image the results. Additional detectors can be inserted to image backscattered electrons as well as secondary electrons, allow elemental analysis (using an energy-dispersive X-ray spectroscopy (EDS) detector), or even phase detection and crystallographic mapping (using an electron backscatter diffraction detector). FIB milling can be used to cut into, or through, specific features in a thin section or rock chip, allowing the structure perpendicular to the surface to be better visualized (Westall et al. 2006). A number of sequential slices can be milled through an object, with images or other data acquired after each slice has been milled. The latter is termed FIB-SEM nano-tomography and allows the $3 \mathrm{D}$ reconstruction and visualization of microfossils at very high spatial resolutions (for details, see Wacey et al. 2012). The resolution attainable is essentially dictated by the $3 \mathrm{D}$ size of the object to be analysed, plus the available time, although instrumental resolution limits may come into play for very small objects. Slice thicknesses are set by the user and can be $<50 \mathrm{~nm}$; however, for practical reasons $100-200 \mathrm{~nm}$ slices have commonly been used. Proterozoic microfossils have been visualized using FIB-SEM nano-tomography from the $1878 \mathrm{Ma}$ Gunflint Formation (Wacey et al. 2012, 2013), the c. 1700 Ma Ruyang Group (Schiffbauer \& Xiao 2009; Pang et al. 2013) and the $c .1000$ Ma Torridon Group. In the former, FIBSEM data were key in revealing heterotrophic bacteria attached to, and fossilized in the act of decomposing, larger organisms (Wacey et al. 2013). The drawbacks of FIB-SEM nano-tomography include its destructive nature - the analysed specimen is completely consumed and only a digital record of its existence will remain - plus the restrictive timescales involved both in analysing objects $c$. $>30 \mu \mathrm{m}$ in diameter ( 24 hours or more beamtime required) and in processing and reconstructing the data. A number of options exist for processing and visualizing such data (and data from other 3D techniques such as X-ray CT), ranging from freeware products - such as the serial palaeontological image editing and rendering systems SPIERS (Sutton et al. 2012), Drishti (Limaye 2012) and Blender (Garwood \& Dunlop 2014) - to more advanced (but expensive) products such as AVIZO (http://www. vsg3d.com). The choice of software will depend on the budget, time constraints, the quality of the raw data and whether there is an interest in producing just images, or images plus movies (for an overview of the options, see Sutton et al. 2014).

Transmission electron microscopy. The technique of TEM covers a number of separate sub-techniques that can all be performed in a transmission electron microscope. At its most simple, TEM is a very high spatial resolution imaging technique, capable of resolving objects separated by as little as $c .0 .1 \mathrm{~nm}$. A standard TEM image results from variable electron scattering as a beam of electrons is accelerated at high voltage through an ultrathin (ideally $\leq 100 \mathrm{~nm}$ ) sample; a true high-resolution image is a phase-contrast image with atomic-scale resolution, allowing the visualization of the arrangement of atoms within a sample (Williams \& Carter 2009). This provides information about the crystallinity of a sample, its lattice structure and any defects it may have.

Sample preparation is the key to obtaining highquality data and in this regard FIB has revolutionized the use of TEM in Precambrian palaeobiology. Before the advent of FIB, sample preparation for TEM involved either grinding up a rock, extracting organic material by acid maceration, or using ion polishing, meaning that the context of the putative microfossils was often lost. It was very difficult to obtain samples of uniform (and ultrathin) thickness and contamination was widespread. FIB milling now allows individual microfossils, or even specific 


\section{WACEY ET AL.}

parts of individual microfossils, to be targeted with great accuracy in their host thin section. Ultrathin wafers (typically about $15 \mu \mathrm{m} \times 10 \mu \mathrm{m} \times 100 \mathrm{~nm}$ ) can then be extracted from below the surface of the thin section (hence eliminating the possibility of contamination) and mounted on a TEM grid (for an overview, see Wacey et al. 2012).

In addition to morphology, a number of other parameters can also be analysed by TEM, including elemental composition, bonding and oxidation state, crystal structure (leading to mineral identification) and crystal orientation. The elemental composition of a sample can be determined at the nano-scale using either EDS or by isolating and mapping specific energy windows from an electron energy loss spectrum. The fine structure of peaks within an electron energy loss spectrum can also be used to shed light on the bonding and oxidation state of the element of interest - for example, distinguishing disordered carbon from graphite (Buseck et al. 1988) and $\mathrm{Fe}^{2+}$ from $\mathrm{Fe}^{3+}$ (Calvert et al. 2005). For advanced crystallography and mineral identification, selected area electron diffraction provides quantitative information on the distances between atomic planes in crystalline materials and allows the orientation of several grains of the same mineral to be compared with one another.

The technique of TEM has been used in Proterozoic palaeobiology for several decades, with early images of microfossils extracted from their host rock in the $c$. $850 \mathrm{Ma}$ Bitter Springs Formation, Australia reported by Oehler (1977). A number of studies have investigated the wall architecture of Proterozoic acritarchs in an attempt to decode their taxonomic affinities because TEM can detect variations in the electron density and texture of different layers within cell walls at nanometre-scale resolution. These include studies from the $c$. $575 \mathrm{Ma}$ Tanana Formation, Australia (Arouri et al. 1999; Moczydlowska \& Willman 2009), where the recognition of a trilaminar sheath structure was part of a suite of evidence suggesting that the microfossils were chlorophyte algae. TEM helped to elucidate the nanostructure of carbon particles making up the cell wall in the 650 Ma Chichkan Formation, Kazakhstan (Kempe et al. 2005). In the $c .1450 \mathrm{Ma}$ Roper and Ruyang groups of Australia and China, respectively (Javaux et al. 2004), at least four different types of wall ultrastructure suggested a greater diversity of eukaryote clades in these deposits than could have been recognized by standard optical techniques. TEM has also been used to investigate the interplay of microfossil walls with the minerals in which they have been preserved, with studies from the $1878 \mathrm{Ma}$ Gunflint Formation showing how nano-grains of silica disrupt the carbonaceous walls of bacteria as they are fossilized (Moreau \& Sharp 2004; Wacey et al. 2012). Data from the c. 750 Ma Draken Formation, Svalbard showed both the cell membrane and cytoplasm of the coccoid microfossil Myxococcoides embedded within nano-grains of silica (Foucher \& Westall 2013). TEM data from the $c .580$ Ma Doushantuo Formation, China helped to decode the relationships between preserved microfossils and the phosphate granules in which they were contained and suggested that phosphate precipitation was likely to have been microbially mediated (She et al. 2013).

Secondary ion mass spectrometry. As applied to the field of Proterozoic palaeobiology, SIMS is a surface analysis technique, whereby the elemental or isotopic composition of a sample can be determined at moderate to high spatial resolution and with great sensitivity (i.e. many elements can be detected even when present at only the parts per billion level). The surface of a sample is sputtered with an ion beam and the secondary ions ejected from the sample are collected and analysed using a mass spectrometer (for details, see Ireland 1995). Two different types of SIMS instruments are commonly used in palaeobiological investigations.

(1) The large radius secondary ion mass spectrometer is used to accurately determine the stable isotope ratios of key biogenic elements (e.g. carbon, sulphur), plus the ratios of radiogenic isotopes, in order to date rock formations containing microfossils (see, for example Stern et al. 2009; Farquhar et al. 2013; Williford et al. 2013). Such instruments can analyse objects as small as $c$. $10-20 \mu \mathrm{m}$ in diameter and the isotopic data can have a precision better than 0.5 parts per thousand (\%o).

(2) In NanoSIMS, the mass spectrometer has a different geometry and is thus capable of element (ion) mapping with a lateral resolution down to c. $50 \mathrm{~nm}$ (see Kilburn \& Wacey 2015 for details). The NanoSIMS instrument can also give accurate isotopic measurements from objects $<5 \mu \mathrm{m}$, albeit with poorer precision (generally $>1 \%$ o) than the large radius secondary ion mass spectrometer.

Both forms of SIMS can be applied to surface features in standard geological thin sections and rock chips, although some specialist sample preparation is needed so that the sample and appropriate standards can be correctly mounted together within the instrument. This generally involves mounting pieces of thin sections or rock chip alongside analytical standards in resin discs. SIMS is partially destructive in that layers of the surface material (as deep as c. $200 \mathrm{~nm}$ during isotope analysis with large radius SIMS) are consumed during the analysis. Small specimens may be entirely consumed by the analysis, whereas larger specimens can be repolished after analysis to look like new. 
A number of Proterozoic microfossils have been analysed by SIMS in the last 15 years. House et al. (2000) were the first to determine the carbon isotope composition of individual microfossils using material from the c. $850 \mathrm{Ma}$ Bitter Springs and $1878 \mathrm{Ma}$ Gunflint formations, finding $\delta^{13} \mathrm{C}$ signatures $(-21$ to $-45 \%$ o) consistent within specific metabolic pathways (namely the Calvin cycle and acetyl-CoA). This work was refined by Williford et al. (2013), who analysed microfossils from four Proterozoic assemblages (Gunflint, Bitter Springs, plus the $c .650$ Ma Chichkan and $c .740$ Ma Min'yar formations) with greater precision and reproducibility. They were able to show considerable variability of $\delta^{13} \mathrm{C}$ within individual assemblages that may reflect the preservation of the original metabolic differences between different components of each biota and also potential heterogeneities in molecular preservation in single microfossils. It must be noted at this stage that non-biological reactions are able to produce similar $\delta^{13} \mathrm{C}$ fractionations (McCollom \& Seewald 2006), so a $\delta^{13} \mathrm{C}$ value must be supported by a definitive biological morphology to prove the biogenicity of ancient carbonaceous objects.

SIMS has also been used to investigate metabolic pathways involving sulphur in Proterozoic organisms. Wacey et al. (2013) determined the $\delta^{34} \mathrm{~S}$ composition of pyritized microfossils from the 1878 Ma Gunflint Formation, finding sulphur fractionations $\left(\delta^{34} \mathrm{~S}=+7\right.$ to $+22 \%$ ) consistent with pyrite formation via the activity of sulphate-reducing bacteria in sulphate-starved sediment pore waters. In the same study, Wacey et al. (2013) used NanoSIMS to map the residual carbon and nitrogen associated with the pyritized microfossils and found reproducible differences in the preservation of organic material between two different types of organism (Huroniospora v. Gunflintia). Gunflintia was poorly preserved, which suggests that it was more prone to decay by heterotrophic bacteria (that also mediated pyrite formation) than Huroniospora. NanoSIMS mapping of organic microfossils in the $c .850 \mathrm{Ma}$ Bitter Springs Formation has shown the co-occurrence of carbon, nitrogen and sulphur in such microstructures (Oehler et al. 2006) and attempts have been made to quantify the ratios of nitrogen to carbon to distinguish different components of microbial communities, or to distinguish biological from co-occurring abiotic organic material (Oehler et al. 2009; Thomen et al. 2014), although the SIMS community has yet to agree on the robustness of these methods.

\section{A Proterozoic case study: the 1200-1000 Ma Torridonian lakes}

The effectiveness of combining multiple high spatial resolution in situ techniques is demonstrated here using a case study of microfossils from the 1200-1000 Ma Torridonian Supergroup of NW Scotland. Not all the described techniques were applied to the Torridonian material to avoid the duplication of data and to keep costs and processing times to reasonable levels. For example, we felt in this case that higher quality $3 \mathrm{D}$ morphological data could be acquired using FIB-SEM rather than CLSM, and that the detailed chemistry could be better (and more cheaply) determined using TEM rather than X-ray spectroscopy. We present data obtained from light microscopy, SEM, $\mu C T$, laser Raman, NanoSIMS, TEM and FIB-SEM nanotomography, which together provide a detailed characterization of a number of components of the Torridonian biota.

\section{Methods}

Optical microscopy. Polished and uncovered petrographic thin sections of 30 and $100 \mu \mathrm{m}$ thickness were examined under Nikon Optiphot-Pol and Nikon Optiphot- 2 microscopes with $4 \times, 10 \times$, $20 \times, 40 \times$ and $100 \times$ (oil immersion) lenses at the Department of Earth Sciences, University of Oxford and with a Leica DM2500M microscope with $4 \times$, $10 \times, 20 \times$ and $50 \times$ lenses at the Centre for Microscopy Characterisation and Analysis (CMCA), The University of Western Australia. Images were captured using Synchroscopy imaging software (Acquis and Auto-montage) at Oxford and using Toupview imaging software at CMCA. Post-processing, for example the colouring of cells in Figures 2 and 3, was carried out in Adobe Photoshop (GIMP is an open source alternative).

Scanning electron microscopy of palynological specimens. Palynological samples were prepared at the Department of Animal and Plant Sciences, University of Sheffield using conventional acid maceration techniques (Grey 1999). Following $\mathrm{HCl}-\mathrm{HF}-\mathrm{HCl}$ acid maceration, the residues were sieved using a $10 \mu \mathrm{m}$ mesh. They were then treated to a heavy liquid separation using zinc chloride, followed by further sieving at $10 \mu \mathrm{m}$. The organic residues were mounted directly onto glass slides using epoxy resin. SEM imaging was carried out using a JEOL JSM-840A scanning electron microscope at the Department of Earth Sciences, University of Oxford.

X-ray micro-computed tomography. Computed tomography scans were performed at the Manchester X-ray Imaging Facility using a Nikon Metris $225 / 320 \mathrm{kV}$ X-ray CT system in a customized bay (tungsten reflection target; current/voltage of $130 \mu \mathrm{A} / 80 \mathrm{kV}$; no filtration; 3142 projections of $708 \mathrm{~ms}$ exposure collected with a $2000 \times 2000$ 


\section{WACEY ET AL.}

detector; reconstructed dataset $5.1 \mu \mathrm{m}$ voxels) and a Zeiss Xradia Versa 520 system (standard transmission target; current/voltage of $62 \mu \mathrm{A} / 160 \mathrm{kV}$; standard in-built, high-energy 2 Zeiss filter; $4 \times$ optical magnification; 501-1001 projections of exposures between 0.5 and $2 \mathrm{~s}$ collected with $4 \times$ binning using a $2000 \times 2000$ detector; reconstructed datasets with 1-2 $\mu \mathrm{m}$ voxel size). Additional propagation-based phase-contrast scans were performed at the TOMCAT beamline of the Swiss Light Source (Paul Scherrer Institut, Villigen, Switzerland; 1001 projections of $700 \mathrm{~ms}$ exposure; $37 \mathrm{keV}$ monochromatic beam; $4 \times$ objective; a LAG:Ce $100 \mu \mathrm{m}$ scintillator; reconstructions based on both attenuation and phase used to create datasets with $1.625 \mu \mathrm{m}$ voxels). Datasets were reconstructed using the SPIERS software suite (Sutton et al. 2012), following the methods of Garwood et al. (2012), and Drishti (Limaye 2012), following the methods of Streng et al. (2016).

Laser Raman spectroscopy. Laser Raman analyses were carried out at the University of Bergen using a Horiba LabRAM HR800 integrated confocal Raman system and LabSpec5 acquisition and analysis software. Samples were standard uncovered geological thin sections, which allowed optical and chemical maps to be superimposed. All analyses were carried out using a $514.5 \mathrm{~nm}$ laser, $100 \mu \mathrm{m}$ confocal hole, 1800 grating and $50 \times$ objective lens. The laser was focused at least $1 \mu \mathrm{m}$ below the surface of the thin sections to avoid surface polishing effects. For mineral identification from Raman spectra, dual acquisitions were taken from each analysis point, each with an acquisition time of $4 \mathrm{~s}$. Raman maps were acquired with a $1.5 \mu \mathrm{m}$ spatial resolution.

Transmission electron microscopy of focused ion beam milled wafers. The TEM wafers were prepared using two dual-beam FIB systems (FEI Nova NanoLab) at the Electron Microscopy Unit of the University of New South Wales and at Adelaide Microscopy at the University of Adelaide. Electron beam imaging was used to identify the microfossils of interest in standard polished thin sections coated with $c .30 \mathrm{~nm}$ of gold, allowing site-specific TEM samples to be prepared. The TEM sections were prepared by a series of steps involving different $\mathrm{Ga}^{+}$ ion beam energies and currents (see Wacey et al. 2012), resulting in ultrathin wafers of $c .100 \mathrm{~nm}$ thickness. These TEM wafers were either attached to Omniprobe copper TEM holders or deposited on continuous-carbon copper TEM grids. TEM data were obtained using an FEI Titan G2 80-200 TEM/STEM system with ChemiSTEM Technology operating at $200 \mathrm{kV}$, plus a JEOL $2100 \mathrm{LaB}_{6}$ transmission electron microscope operating at
$200 \mathrm{kV}$ equipped with a Gatan Orius chargecoupled device camera and Tridiem energy filter. Both instruments were located at CMCA.

Nano secondary ion mass spectrometry. Ion mapping was performed using a CAMECA NanoSIMS 50 system at CMCA, with instrument parameters optimized as described in Wacey et al. (2011). Analysis areas were between $12 \times 12 \mu \mathrm{m}$ and $25 \times$ $25 \mu \mathrm{m}$ with a resolution of $256 \times 256$ pixels (so each pixel measured between 47 and $98 \mathrm{~nm}$ ), with a dwell time of 5-15 ms per pixel and a primary beam current of $c .2 .5 \mathrm{pA}$. The secondary ions mapped were ${ }^{24} \mathrm{C}_{2}^{-},{ }^{12} \mathrm{C}^{14} \mathrm{~N}^{-},{ }^{28} \mathrm{Si}^{-},{ }^{32} \mathrm{~S}^{-}$and ${ }^{56} \mathrm{Fe}^{16} \mathrm{O}^{-}$; charge compensation was achieved using the electron flood gun.

Focused ion beam scanning electron microscopy nano-tomography. Sequential FIB milling and SEM imaging was carried out on a Zeiss Auriga Crossbeam instrument at the Electron Microscopy Unit of the University of New South Wales using the method of Wacey et al. (2012, 2014). Key parameters were adjusted to suit the specific size and nature of each sample of interest. Initial trenches were milled using a $9 \mathrm{nA}$ beam current and the imaged face was cleaned using a $2 \mathrm{nA}$ beam current; the ion beam current for slice milling was $2 \mathrm{nA}$, the electron beam voltage for imaging varied between about $800 \mathrm{~V}$ and $5 \mathrm{kV}$, the step sizes between slices were between 75 and $200 \mathrm{~nm}$ and the image capture times were around $30 \mathrm{~s}$ per frame. In some samples, dedicated trenches were milled to obtain elemental (EDS) maps of microfossils that were not subsequently milled for 3D analysis.

To visualize the data, FIB-SEM images were stacked, aligned and cropped using SPIERSalign (Sutton et al. 2012). The resultant stacks were imported into SPIERSedit (Sutton et al. 2012), where a number of masks were added to segment individual components (e.g. cell walls, cell contents) of the microfossil assemblage. The resulting files were exported and loaded into SPIERSview (Sutton et al. 2012) to generate the 3D surface renderings.

\section{Results}

Multiple seasons of fieldwork had been completed to gain a firm understanding of the geological context of the host rocks before the Torridonian microfossils were subjected to the high spatial resolution, in situ microanalysis described here. In addition, over 100 thin sections and hand samples had been studied to understand the depositional context and post-depositional history of the rocks and to isolate only the very best and most promising samples for further study. A large amount of optical microscopy 


\section{ANALYTICAL TECHNIQUES FOR PROTEROZOIC MICROFOSSILS}

work had also been completed to form an estimate of the morphological diversity of the biota. This work has all been peer reviewed and published (Callow et al. 2011; Strother et al. 2011; Battison \& Brasier 2012; Strother \& Wellman 2015), thus giving a firm platform on which to build this highresolution work. A summary of some of the most common components of the Torridonian biota as observed by optical microscopy is given in Figure 1 .

Scanning electron microscopy data. As may be expected, the range of morphologies visible in SEM analysis (Fig. 2) was broadly comparable with that observed within thin sections of the phosphate (Fig. 1, plus Battison \& Brasier 2012). Many simple vesicles and tubular morphotypes were observed, with SEM imaging affording enhanced resolution of their shape and wall structure. In particular, differences in the physical responses of structures to compression hint at differences in the cell wall architecture. Two principal wall responses were observed. Thicker walled (wall at least $1 \mu \mathrm{m}$ thick) specimens accommodate flattening with broad, rounded, velvet-like folds or large creases (Fig. 2a). By contrast, thin-walled vesicles $(<0.5 \mu \mathrm{m})$ accommodate compression with fine wrinkles irregularly distributed across the surface and are apparently more prone to small tears (Fig. $2 b)$. The flattening of these walls during preparation does not allow the resolution of any ultrastructural lamination, but a synthesis of the taphonomic response and wall thickness may be used to enhance the interpretation of microfossils studied by optical microscopy.

A number of unique forms of microfossils were also observed by SEM. This is probably due to the processing of larger quantities of material during preparation by acid maceration, as well as the

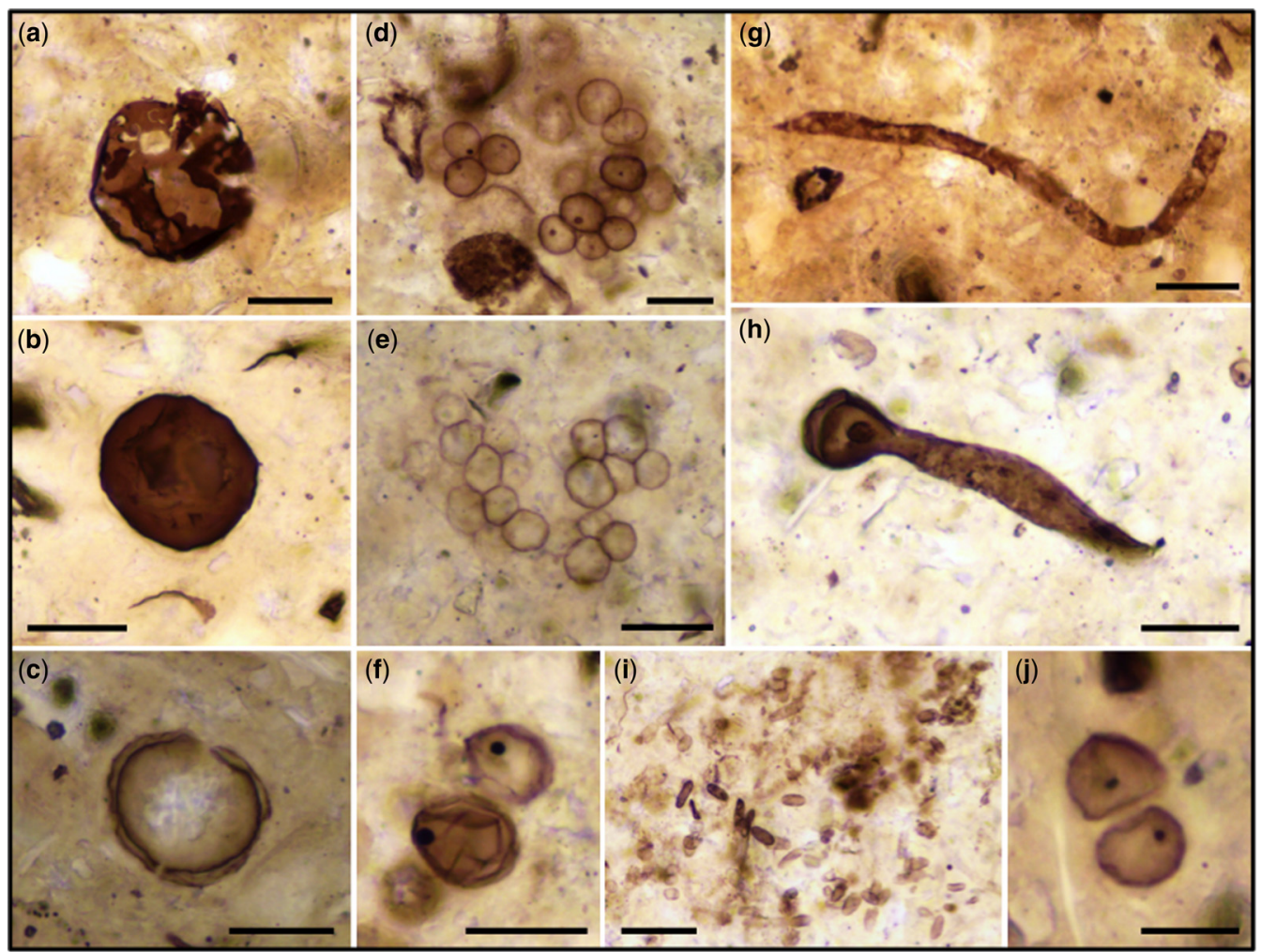

Fig. 1. Optical microscopy of Torridonian microfossils, demonstrating the common morphotypes present in the assemblage. (a) Highly degraded dark-walled vesicle. (b) Pristine dark-walled vesicle. (c) Light-walled vesicle, potentially possessing a double wall. (d) Cluster of light-walled spheroidal unicells, most with a dark spot indicating the potential preservation of cell contents. (e) Cluster of light-walled cells with mutually adpressed cell walls. (f) Pair of spheroidal unicells with very prominent dark inner sphere. (g) Partially decomposed filamentous sheath.

(h) Filamentous sheath with bulbous termination housing potential spheroidal cell. (i) Colony of light-walled elliptical cells comparable to Eohalothece lacustrina described by Strother \& Wellman (2015). (j) Pair of cells that may have divided shortly before fossilization, each containing a dark spot. Scale bars $20 \mu \mathrm{m}$ for (a-i) and $10 \mu \mathrm{m}$ for (j). 

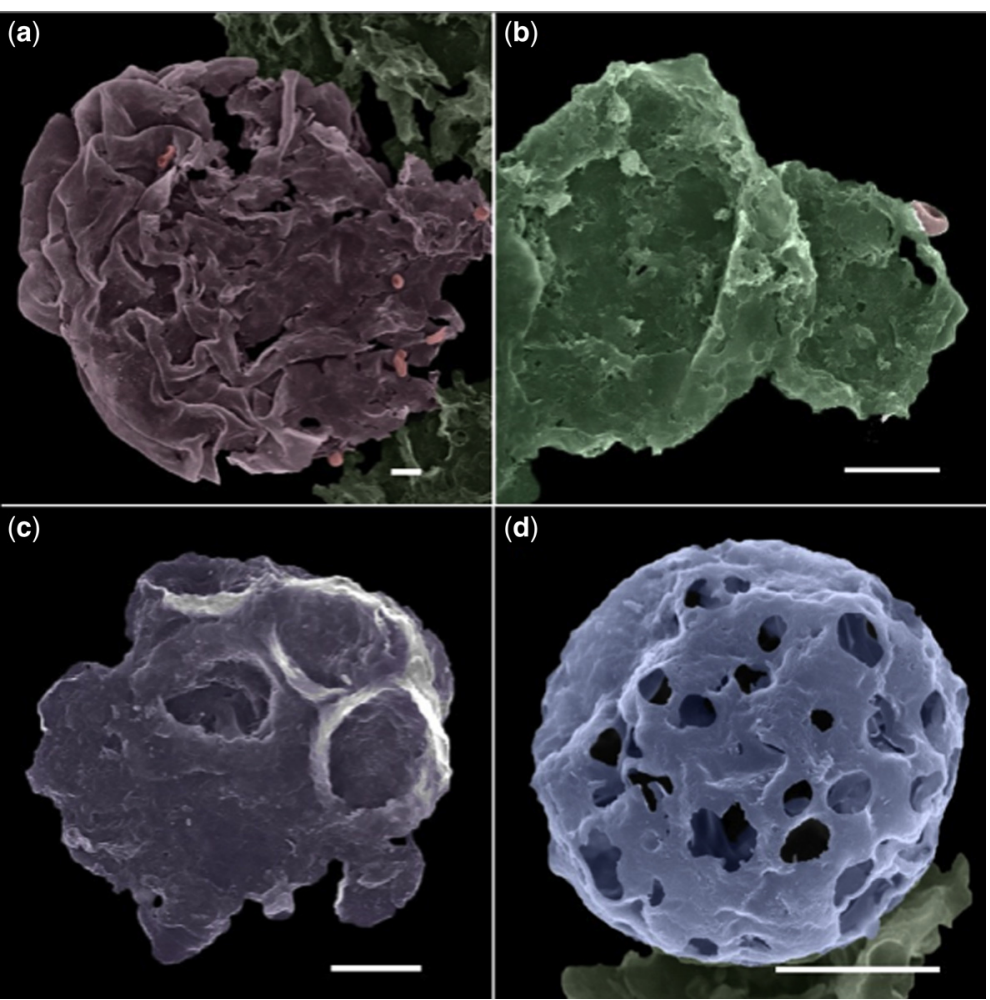

Fig. 2. Torridonian microfossils imaged and analysed by SEM, coloured for easier interpretation. (a) Large, thick-walled vesicle showing velvet-like folds. (b) Smaller, thin-walled vesicles with a crinkled surface and finely irregular outline. (c) Vesicle with large hemispherical pits bounded by raised rims or 'collars'. (d) Subspherical rigid vesicle retaining a 3D structure and bearing many irregular rounded holes. Pink coccoid structures attached to the vesicles ( $a, b)$ are potential fossil heterotrophs (see also Fig. 3). Sample CAI-7, macerated from phosphate from the Cailleach Head Formation. All scale bars $10 \mu \mathrm{m}$.

enhanced resolution afforded by SEM imaging. Of note were two morphotypes, the first (Fig. 2c) consisting of a vesicle $c .50 \mu \mathrm{m}$ in diameter, ornamented with regular pits $c$. $10 \mu \mathrm{m}$ across, with each pit possessing a raised 'collar' $c$. $2 \mu \mathrm{m}$ wide and $2 \mu \mathrm{m}$ high. This form bears some resemblance to the basal vesicle of Cheilofilum hysteriopsis Butterfield (see Butterfield 2005, figs 8 and 10) or the freshwater green microalga Botryococcus braunii (see Vandenbroucke \& Largeau 2007, pl. e) in its possession of flanged openings. The second form (Fig. 2d) is a spherical hollow vesicle $c .20 \mu \mathrm{m}$ in diameter with a spongy textured wall and irregularly distributed, rounded or sub-circular holes c. 1$3 \mu \mathrm{m}$ across. This morphotype is particularly notable for its retention of 3D structure following maceration, indicating significant rigidity of the wall. In addition, non-vesicular membranous organic matter with an irregularly pustulate and pitted texture and an amorphous architecture was distributed abundantly among the structurally distinguishable vesicles and sheaths. The size and nature of this material was similar to the amorphous extra-polymeric substances secreted by mat-forming organisms in modern microbial ecosystems (cf. Pacton et al. 2007), but could also be amorphous kerogen. This material was occasionally seen contained within thin sections as a light-walled membrane, but its texture and extent was clearer under SEM analysis.

Of particular note among the vesicles, sheaths and putative extra-polymeric substances were small coccoid or baccilate forms seen to be colonizing, to varying degrees, some of the larger fossil structures. These were associated with pits within those larger structures and were apparently embedded within a membrane that linked them to the host fossil (Fig. 3). We interpreted these forms as fossils of heterotrophic bacteria preserved feeding on the larger Torridonian microbial flora and this interpretation reinforced observations made previously using light microscopy (see Battison \& 

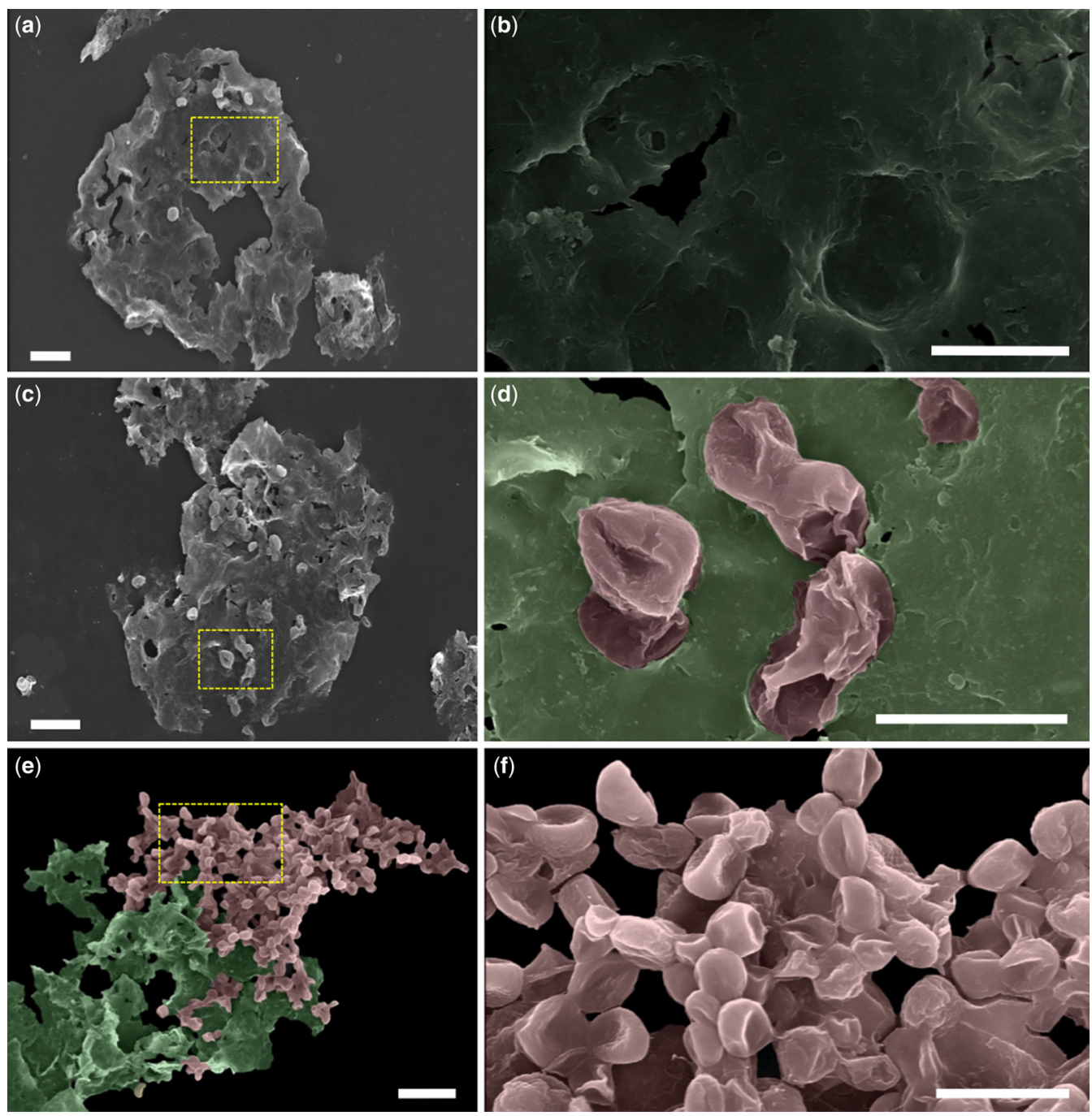

Fig. 3. Evidence of bacterial heterotrophy in SEM images. (a, b) Rounded pits and occasional holes, irregularly distributed on the surface of the walls of larger vesicles; (b) is an enlargement of boxed area in (a). (c, d) Collapsed coccoid or baccilate cells $c .5 \mu \mathrm{m}$ across, occupying pits in the walls of larger vesicles, occasionally with a thin raised lip; (d) is an enlargement of boxed area in (c) with heterotrophs false-coloured pink. (e) Densely packed colony of coccoid and baccilate cells (pink) continuous with amorphous degraded vesicular or extra-polymeric substances material (grey-green). (f) Higher magnification of colony in boxed area of (e) showing collapsed coccoid and baccilate structures arranged randomly with possible supporting and sheathing membrane. Sample CAI-7, macerated from phosphate from Cailleach Head Formation. Scale bars $20 \mu \mathrm{m}$ for (a, c, e) and $10 \mu \mathrm{m}(\mathrm{b}, \mathrm{d}, \mathrm{f})$.

Brasier 2012, fig. 9, where evidence for heterotrophy included roughly circular holes in large microfossil vesicles and inferred clumps of heterotrophic bacteria pseudomorphing decayed vesicles).

$X$-ray micro-computed tomography data. Micro-CT was explored as a method to investigate the petrographic context of cellular material and was also tested to determine whether individual microfossils could be detected and their 3D morphology characterized. Scans of rock chips from the Cailleach Head Formation using a Nikon Metris 225/320 kV $\mathrm{X}$-ray CT system with $5.1 \mu \mathrm{m}$ voxels revealed phosphate nodules as a slightly denser phase that could be distinguished from the surrounding matrix sediment (Fig. 4a, purple colour). It also suggested that phosphate was present in small quantities close to, but exterior to, the main nodule. Rounded 

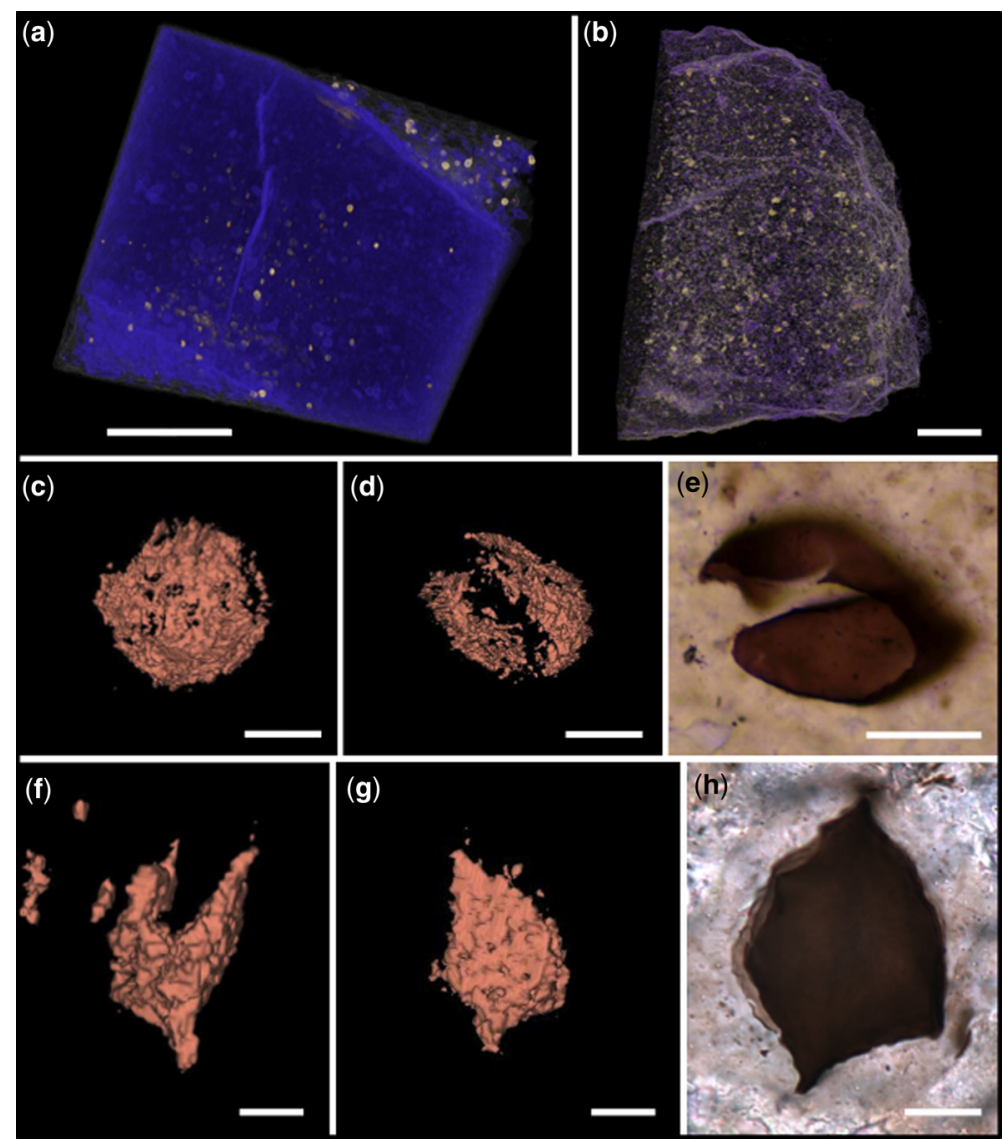

Fig. 4. X-ray microtomography analysis of Torridonian rock chips. (a) Reconstruction of a CT scan of a rock chip using the Nikon instrument (voxels $c .5 \mu \mathrm{m}$ ), highlighting part of a phosphate nodule (purple) within a quartz-rich sediment (grey), plus a number of higher density grains that are probably pyrite or iron oxide (gold coloured). (b) Reconstruction of an X-ray scan of a second rock chip using the Swiss Light Source Synchrotron (voxels $1.625 \mu \mathrm{m}$ ). This shows a mixture of phosphate and other denser phases rather evenly distributed through the rock chip with no distinct phosphate nodule. (c, $\mathbf{d}$ and $\mathbf{f}, \mathbf{g})$ Reconstruction of two putative vesicles identified in a higher resolution CT scan using the Zeiss Xradia Versa instrument (voxels $c .1 .5 \mu \mathrm{m}$ ). The light micrograph images (e and h) show specimens observed in thin sections that may be analogous to those identified using CT. Scale bars $2 \mathrm{~mm}$ for (a), $500 \mu \mathrm{m}$ for (b) and $20 \mu \mathrm{m}$ for (c-h).

concentrations of a very dense phase, most likely to be an iron-rich mineral such as pyrite or iron oxide, were shown to be present both within and outside the nodule (Fig. 4a, gold colour). Hence CT could be used in future investigations as a pre-screen of rock fragments to determine the best position within the rock from which to cut thin sections. The Nikon CT scans detected phases of lower density within the phosphate nodules that may be organic microfossils. However, the spatial resolution of this instrument was insufficient to determine whether these lower density objects were indeed microfossils or simply lower density sediment grains (e.g. quartz) scattered through the phosphate nodules.
Higher resolution scans of a different rock chip (with $1.625 \mu \mathrm{m}$ voxels) conducted at the Swiss Light Source demonstrated a complex sedimentary texture - here both phosphate and other dense phases were present in the form of evenly spaced rounded to angular fragments within the scanned rock chips (Fig. 4b), with no evidence of wellformed nodules of phosphate. The lack of evidence for nodules suggested that this rock chip would not be a promising target for the further investigation of microfossils.

The CT scans of a sub-portion of the sample examined in the Nikon instrument, performed using a Zeiss Xradia Versa 520 with voxels of 


\section{ANALYTICAL TECHNIQUES FOR PROTEROZOIC MICROFOSSILS}

c. $1.5 \mu \mathrm{m}$, detected a small number of low-density objects that strongly resembled the microfossils observed in thin sections (Fig. 4c, d, f and g). These objects were analogous to some of the largest and darkest walled vesicles seen in thin section (Fig. 4e, h) and CT allowed them to be viewed from multiple orientations in 3D space. These putative fossils were also frequently found close to the very high density phases (presumably iron oxide or pyrite). The combined evidence suggested that $\mu \mathrm{CT}$ at this resolution was only capable of detecting the largest and thickest walled components of the Torridonian biota. We also suggest that the increased density contrast when such fossils occur in close proximity to iron oxide or pyrite aids detection by CT. The remaining components of the biota (e.g. the examples shown in Fig. 1) are essentially invisible on X-ray CT scans conducted at these resolutions. The biggest challenge for future work will be identifying workflows to isolate known microfossils for future scanning.

Raman spectroscopy data. Raman data inform about the dominant mineralogy of the Torridonian microfossils and their surrounding matrix, plus the structure and thermal history of any organic carbon present. Raman maps from the Cailleach Head Formation (Fig. 5a-c) demonstrated that the microfossils were indeed carbonaceous (Fig. 5b) and that the dominant fossilizing phase was apatite (Fig. 5c). Raman spectroscopy also showed that the intracellular inclusions (Fig. 5a arrows), common in many of the spheroidal fossils from this formation, were also carbonaceous in composition. Hence these inclusions probably represent plasmolysed (shrunken) cell contents or, in some cases, could represent a fossilized cell nucleus. The Raman spectra in the first-order region of carbon showed the two main bands (D1 at about $1350 \mathrm{~cm}^{-1}$ and $\mathrm{G}$ at about $1600 \mathrm{~cm}^{-1}$ ) characteristic of disordered carbonaceous material. The D1 band was very broad (full width at half peak maximum of $c .120 \mathrm{~cm}^{-1}$ ) with a shoulder on its low wavenumber side. This shoulder was caused by a small band at $c .1150 \mathrm{~cm}^{-1}$, which was only observed in very disordered carbonaceous material (Marshall et al. 2005). The G band appeared to have been shifted considerably from its value in crystalline graphite $\left(1582 \mathrm{~cm}^{-1}\right)$ to a value of $c .1610 \mathrm{~cm}^{-1}$. This reflected an overlap of the $\mathrm{G}$ band with a well-developed disorder band (D2) at $c .1620 \mathrm{~cm}^{-1}$. The spectrum indicated that the carbonaceous material had a very weak
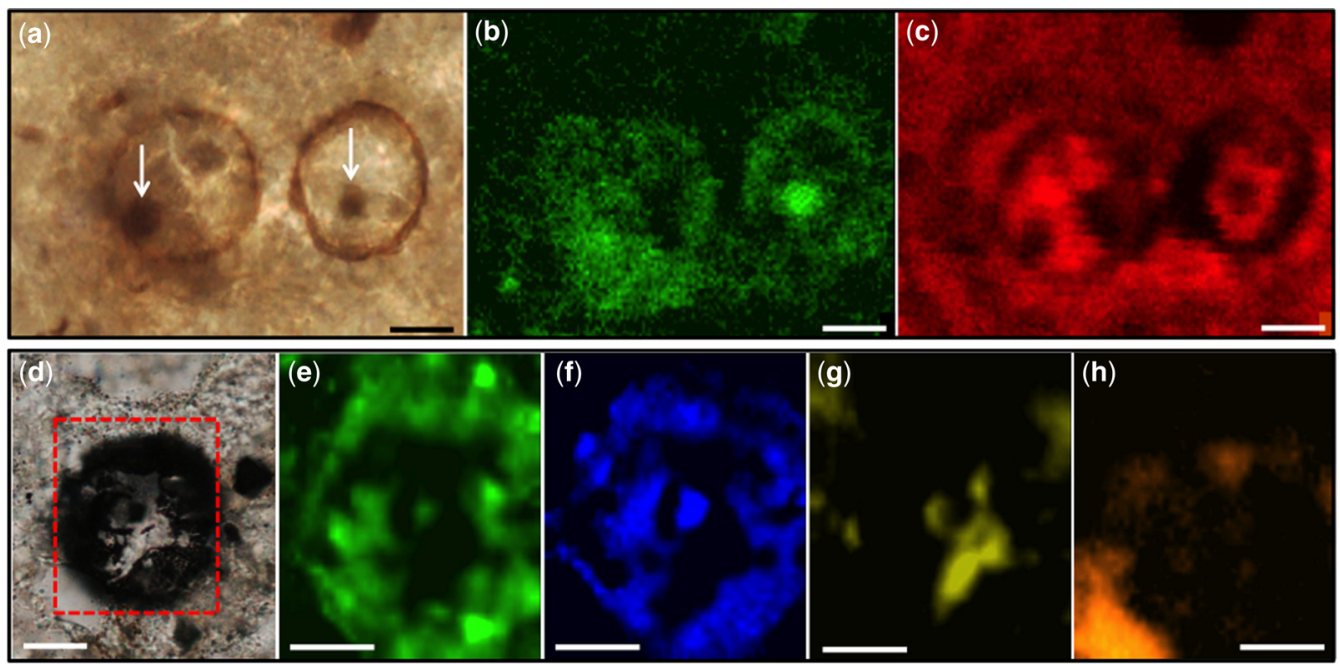

Fig. 5. Raman analysis of microfossils from the Torridonian Supergroup. (a) Optical photomicrograph of two coccoid microfossils from the Cailleach Head Formation, each containing dark interior spheroids (arrows). (b) Raman map of the carbon $\mathrm{G} c .1600 \mathrm{~cm}^{-1}$ peak showing that the microfossils have carbonaceous walls and the dark interior spheroids are also carbonaceous. This suggests that they are clumps of degraded cellular material or remnants of a cell nucleus. (c) Raman map of the major calcium phosphate (apatite) $c .960 \mathrm{~cm}^{-1}$ peak showing that a large proportion of the mineralizing phase is apatite. The patchy appearance of the apatite suggests the presence of further mineral phases, interpreted to be clay minerals as detected in higher resolution SEM and TEM analyses (see Figs 7 \& 8). (d) Optical photomicrograph of a microfossil from the Stoer Group. Raman maps of (e) the carbon G $c$. $1600 \mathrm{~cm}^{-1}$ peak, (f) the pyrite $c .380 \mathrm{~cm}^{-1}$ peak, (g) the calcite $c .1090 \mathrm{~cm}^{-1}$ peak and (h) the albite $c .510 \mathrm{~cm}^{-1}$ peak demonstrating that the microfossil is partially pyritized, but some carbonaceous composition remains and that the sediment is dominantly calcite and feldspar. Scale bars $10 \mu \mathrm{m}$. 


\section{WACEY ET $A L$.}

structural organization, had experienced little or no metamorphism (cf. Wopenka \& Pasteris 1993) and was consistent with the previously suggested maximum heating of only $c .100^{\circ} \mathrm{C}$ (Stewart \& Parker 1979).

Not all microfossils are preserved purely as carbon. In the Stoer Group, Raman spectroscopy revealed that significant portions of the microfossil walls have been pyritized, although some carbonaceous signal remains (Fig. 5d-f). The matrix mineralogy was also different here, with typical phases including calcite and albitic feldspar (Fig. 5g, h). These data indicated that different suites of lakes within the Torridonian had different chemistries, with those of the Stoer Group being sulphate-rich and phosphate-poor compared with those of the Cailleach Head and Diabaig formations (for further details on contrasting fossil preservation in these lakes, see Wacey et al. 2016).
NanoSIMS data. The NanoSIMS technique was used as an additional tool to determine whether the microfossils were composed of carbonaceous material and then to determine whether any additional elements of biological interest were preserved within their cell walls or intracellular space. NanoSIMS uniquely revealed significant (but not quantifiable) amounts of nitrogen and sulphur within cellular material from the Diabaig Formation (Fig. 6). These data were collected from FIB-milled wafers and so the nitrogen and sulphur came from cell walls located below the surface of a thin section. This negated the possibility that these biological signals came from surface contamination and provided an improvement on previous NanoSIMS methodology where ion mapping was performed on surface features (e.g. Oehler et al. 2006, 2009). The co-occurrence of $\mathrm{C}, \mathrm{N}$ and $\mathrm{S}$ in microstructures that have a cellular morphology is strong evidence

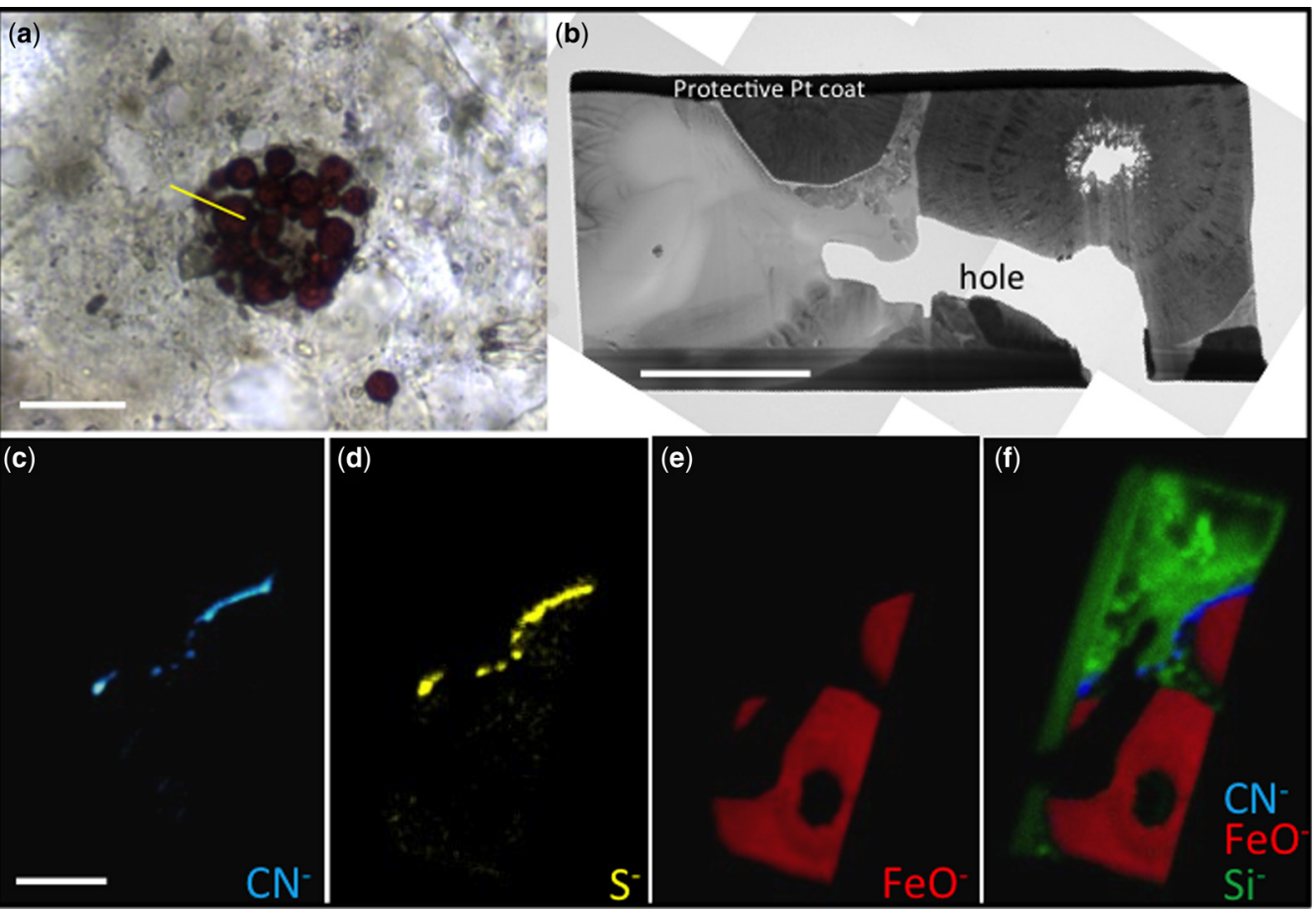

Fig. 6. NanoSIMS analysis of a microfossil from the Diabaig Formation. (a) Optical photomicrograph of a light-walled spheroidal cell with ruby red intracellular particles. (b) Overview of a FIB-milled wafer prepared for NanoSIMS from the region indicated by the yellow line in (a). Note the contrast between the large dark grey grains, which equate to the ruby red grains in (a), and the remainder of the wafer, plus holes in the wafer probably induced by excessive FIB milling. (c) NanoSIMS ion map of nitrogen measured as $\mathrm{CN}^{-}$. (d) NanoSIMS ion map of sulphur measured as $\mathrm{S}^{-}$. (e) NanoSIMS ion map of iron oxide measured as $\mathrm{FeO}^{-}$. (f) Three-colour overlay of nitrogen (blue), iron oxide (red) and silicon (green) showing that the large dark grains are iron oxides and they are located just inside the cell wall (intracellular). The other mineral phases are dominantly clays and quartz. Scale bar $20 \mu \mathrm{m}$ in (a) and $5 \mu \mathrm{m}$ for $(\mathrm{b}-\mathrm{f})$. Note scale bar in (c) also applies to (d-f). 
929

$92 n$

920

9

9 hard

935

936

937

938

939

940

941

942

943

944

945

946

947

948

949

950

951

952

953

954

955

956

957

958

959

960

961

962

963

964

965

966

967

968

969

970

971

972

973

974

975

976

977

978

979

980

981

982

983

984

985

986
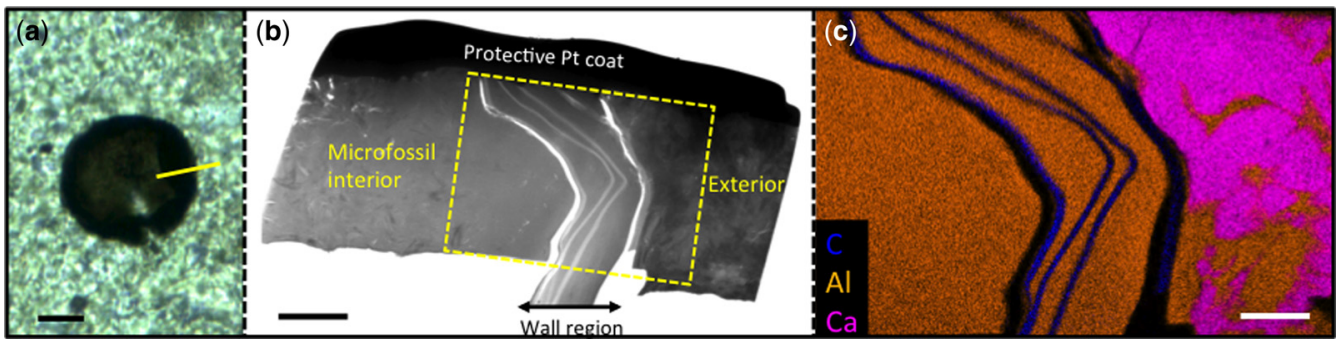

Fig. 7. TEM analysis of a FIB milled wafer extracted from a Torridonian microfossil. (a) Optical photomicrograph of a dark-walled spheroidal microfossil from the Cailleach Head Formation. (b) Overview of the FIB-milled wafer extracted from the region marked by the yellow line in (a) showing a complex wall structure and different mineral phases (indicated by different levels of grey within the image) inside and outside of the microfossil (from Wacey et al. 2014). (c) Three-colour overlay of ChemiSTEM elemental maps of carbon (blue), aluminium (orange) and calcium (pink) from the region indicated by the dashed box in (b). Carbon represents the organic material of the microfossil walls and at least four separate walls (or wall layers) can be seen. Calcium represents apatite, the dominant mineral phase outside the microfossil. Aluminium represents clay minerals that infill the microfossil, occur between the walls of the microfossil and occur in minor amounts outside the microfossil. Black areas are holes in the TEM wafer. Scale bar $10 \mu \mathrm{m}$ in (a), $2 \mu \mathrm{m}$ in (b) and $1 \mu \mathrm{m}$ in (c).

of the biogenicity of such structures. Although this is less relevant to the Torridonian material, the biogenicity of which is well accepted, it is a very useful tool for the investigation of older and/or more controversial fossil material. Building up a database of the $\mathrm{C}, \mathrm{N}$ and $\mathrm{S}$ concentrations of different types of organic material may also be useful in helping to determine whether different components of cells (i.e. the cell wall, membrane, nucleus and cytoplasm) can be preserved in exceptional circumstances. NanoSIMS also revealed the nature of some non-carbonaceous intracellular inclusions within the Diabaig Formation. These inclusions are ruby red in colour in optical microscopy (Fig. 6a) and NanoSIMS showed that they were iron oxides (Fig. 6e, f) and that at least some occurred in direct contact with the inner cell wall. These inclusions were rare, found in $<1 \%$ of Torridonian microfossils, but may indicate a unique intracellular chemistry in this small proportion of specimens.

Transmission electron microscopy data. The TEM data revealed the chemistry of the fossilizing mineral phases and the ultrastructure of the microfossils at a spatial scale (nanometres) unattainable by any other technique. For example, ChemiSTEM (STEM-EDS) elemental mapping combined with selected area electron diffraction has shown that phosphate is not necessarily the dominant mineral responsible for the exceptional microfossil preservation in the Cailleach Head and Diabaig formations (cf. Raman and optical data). In fact, the minerals immediately adjacent to most vesicle walls are ironrich clay minerals of the chlorite group or potassium-rich clay minerals similar to illite (Fig. 7; see Wacey et al. 2014 for details on clay mineral identification). Phosphate only dominates at some distance (tens to hundreds of nanometres) away from the cellular material. The interiors of many microfossils were also filled with potassium-rich clay minerals (Fig. 7), although phosphate grains were also common in many cell interiors (e.g. Wacey et al. 2014, fig. 8). STEM-EDS in the transmission electron microscope detected small $\mathrm{C}$ and $\mathrm{F}$ peaks in the phosphate spectra, confirming that the phosphate was francolite (carbonate fluorapatite), the common low-temperature form often associated with fossils.

The TEM imaging revealed sub-components of microfossil walls that were not previously recognized. In many cases a presumed single, thick vesicle wall was shown to consist of multiple components. These included a thicker inner wall sitting within a thinner outer wall, perhaps suggesting a cyst housed within a vegetative cell, or even more complex arrangements of up to four distinct layers within a 'wall zone' (Fig. 7). Such arrangements are too complex for simple prokaryote cells. Hence this strongly suggested a eukaryotic component to the biota. These complex layered walls were also preserved in clay minerals. Hence the combined data suggested that the fidelity of microfossil preservation may be enhanced by the early precipitation of clay minerals and that microfossil preservation in clay minerals may be of even higher quality than in phosphate.

Focused ion bean scanning electron microscopy data. Two types of data were acquired using FIB-SEM: chemical and 3D morphological. Chemical data were acquired by simply slicing into a microfossil using an FIB and then analysing the chemistry of a cross-section through the microfossil using SEM-EDS. This provided similar data to 
1004

1005

1006

1007

1008

1009

1010

1011

1012

1013

1014

1 1 5

online/

colour

hardcopy

IU1Y

1020

1021

1022

1023

1024

1025

1026

1027

1028

1029

1030

1031

1032

1033

1034

1035

1036

1037

1038

1039

1040

1041

1042

1043

1044

(a)

(b)
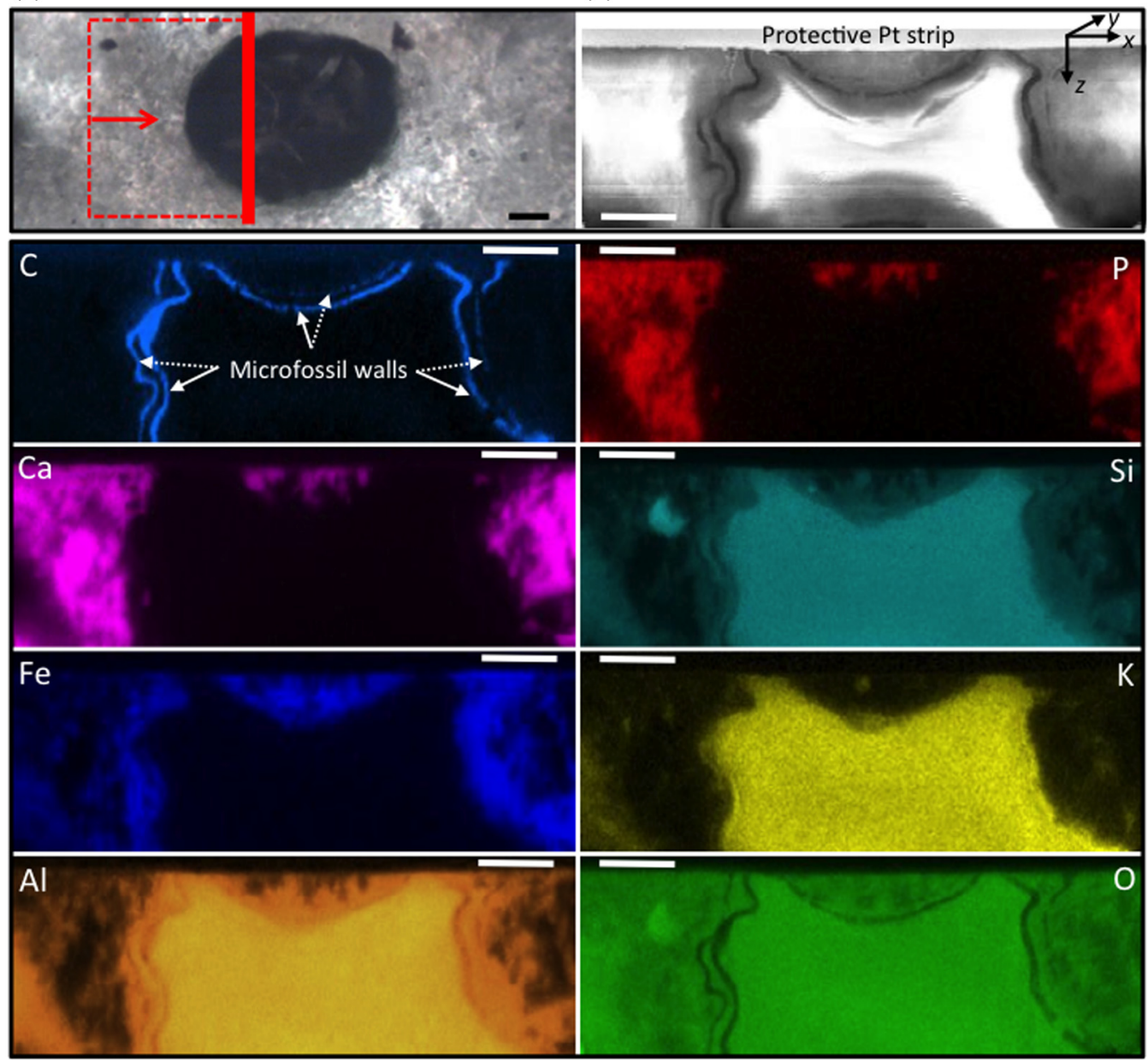

Fig. 8. FIB-SEM-EDS analysis of a microfossil from the Cailleach Head Formation. (a) Optical photomicrograph of a dark-walled spheroidal vesicle showing the location of the FIB-milled area and direction of view for the other panels in the figure (from Wacey et al. 2014). (b) Secondary electron image showing the FIB-milled face below the surface of the thin section. The EDS elemental maps of the FIB-milled face shown in (b) are given below. Carbon (light blue) represents the organic microfossil walls, highlighting a thick inner cyst wall and thinner outer vegetative cell wall. Phosphorus (red), calcium (pink) and moderate levels of oxygen (green) represent apatite, the dominant fossilizing mineral outside the microfossil. Iron (blue), plus moderate amounts of silicon (turquoise), aluminium (orange) and oxygen, represents iron-rich clay, occurring between the two microfossil walls, replacing parts of the outer wall and continuing for 1-2 $\mu \mathrm{m}$ outside the outer wall. Potassium (yellow), plus silicon, aluminium and oxygen represents potassium-rich clay restricted to the interior of the vesicle. Scale bars $5 \mu \mathrm{m}$.

STEM-EDS in TEM, but at a more flexible spatial scale (i.e. it could be applied to larger fossils, albeit at a lower spatial resolution). These data reinforced those acquired using TEM, showing that, in fossils with complex walls (interpreted as eukaryotes), clay minerals occurred in direct contact with microfossil walls, in between multiple walls and in microfossil interiors, whereas calcium phosphate tended to occur exterior to the fossil (Fig. 8). The pattern was less defined in simpler prokaryote fossils, with phosphate mixed with clay minerals typically occurring both exterior and interior to the cell (Fig. 9a, b).

Morphological data in three dimensions were acquired using FIB-SEM nano-tomography, whereby sequential FIB slicing was followed by imaging using SEM. This provided an excellent visualization of the cellular material located below the surface of the thin section (Fig. 9b) that would otherwise 
1045

1046

1047

1048

1049

1050

1051

1052

1053

1054

1055

1056

1057

1. Colour

1. online/

1) colour

1, hardcopy

1062

1063

1064

1065

1066

1067

1068

1069

1070

1071

1072

1073

1074

1075

1076

1077

1078

1079

1080

1081

1082

1083

1084

1085

1086

1087

1088

1089

1090

1091

1092

1093

1094

1095

1096

1097

1098

1099

1100

1101

1102
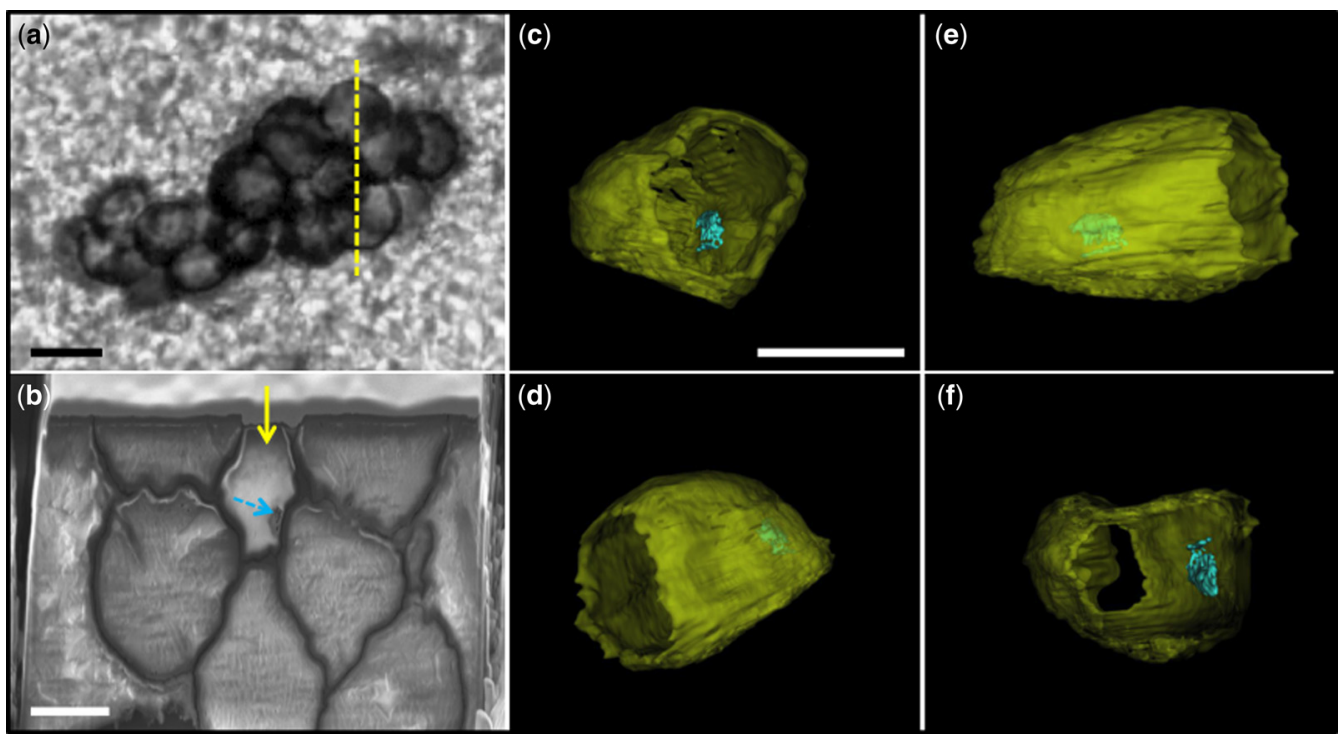

Fig. 9. Three-dimensional FIB-SEM nano-tomography of a Torridon microfossil. (a) Optical photomicrograph of a cluster of light-walled spheroidal cells from the Cailleach Head Formation (from Wacey 2014). (b) Example of an FIB-milled slice through the cluster of microfossils in the region indicated by the dashed line in (a). Note that portions of at least eight cells can be seen in this image, some of which are hidden from view below other cells in the optical photomicrograph. Note also dark material inside the upper central cell (dashed arrow). (c-f) 3D model of the cell indicated by the solid arrow in (b) viewed from four different orientations, showing the location of preserved cell contents (blue) with respect to the cell wall (yellow). Note that part of the cell wall in (f) has been removed to better visualize the cell contents. Scale bar $10 \mu \mathrm{m}$ in (a) and $5 \mu \mathrm{m}$ for (b-f). Note scale bar in (c) also applies to $(\mathrm{d}-\mathrm{f})$.

have been hidden by the overlying fossil material (Fig. 9a). In addition, individual cells and cell contents could be visualized from multiple orientations in 3D space (Fig. 9c-f). This is particularly useful for accurately locating the position of organic intracellular inclusions (Fig. 9c-f). In the example presented here, these inclusions were most likely shrunken remnants of the cytoplasm of simple prokaryote cells, but in future it may be possible to detect the preserved remnants of eukaryotic nuclei or organelles using such methods.

\section{Conclusions}

We have provided an overview of the types of high-resolution techniques currently available to those researchers interested in characterizing Proterozoic microfossils and their associated minerals and fabrics. The techniques have been classified either as non-destructive, hence applicable to all material including holotypes, or destructive, applicable where the conservation of the specimen is not a requirement. Non-destructive techniques include laser Raman spectroscopy, CLSM, SEM, infrared spectroscopy, X-ray CT and X-ray spectroscopy, although specialized (and partly destructive) sample preparation is required to obtain the highest spatial resolution data using the latter two methods. Destructive techniques include SIMS, where the surface layers of a microfossil are sputtered away during analysis, TEM, where an ultrathin slice must be extracted from the microfossil, and FIBSEM nano-tomography, which consumes the entire specimen during analysis.

Maximum information is gained by the consilience of multiple approaches to a microfossil assemblage, but in reality there will be some trade-off between time and budget constraints, efforts to conserve the best specimens and the spatial resolution required. The destructive techniques of TEM and FIB-SEM provide the greatest spatial resolution, whereas SIMS uniquely provides isotopic data. A sensible workflow would involve an analysis of the petrographic context and a significant number of representative specimens using non-destructive avenues, followed by the focused analysis of a few specimens by destructive techniques.

A case study from the Torridonian of NW Scotland, a microfossil assemblage whose importance has been highlighted by work led by Martin Brasier, demonstrated the additional insights that these 


\section{WACEY ET AL.}

high-resolution techniques can offer. Micro-CT provided a rapid way to determine the locality of the phosphate nodules that house microfossils and other petrological details. SEM revealed a number of new morphotyes not previously recognized in optical work and hinted at different taphonomic responses by different types of cell and vesicle walls. TEM revealed the fine-scale distribution of mineral phases in and around the cellular material and showed that clay minerals played an important part in the exceptional preservation of this biota. Raman spectroscopy, together with NanoSIMS, revealed details of the organic material making up the cells, including its thermal maturity and biochemistry in terms of the $\mathrm{C}, \mathrm{N}$ and $\mathrm{S}$ contents. FIBSEM nano-tomography provided a detailed $3 \mathrm{D}$ view of a number of fossilized cells, including the location of the remains of organic cell contents.

We acknowledge the facilities, scientific and technical assistance of the Australian Microscopy and Microanalysis Research Facility at the Centre for Microscopy Characterisation and Analysis, The University of Western Australia and the Electron Microscopy Unit, The University of New South Wales. These facilities are funded by the universities, state and commonwealth governments. We acknowledge the following for technical assistance: Matt Kilburn and Paul Guagliardo for assistance with NanoSIMS; Martin Saunders for assistance with TEM; Charlie Kong for assistance with FIB; Phil Withers and the Manchester $\mathrm{X}$-ray Imaging Facility, which was funded in part by the EPSRC (grants EP/F007906/1, EP/F001452/1 and EP/ I02249X/1); Nicola McLoughlin for access to the University of Bergen laser Raman facility; Owen Green for thin section preparation and access to the Oxford University scanning electron microscopy; Imran Rahman, Alan Spencer, Jonny Waters and Nidia Alvarez for assistance on beamtime and the Paul Scherrer Institut, Villigen, Switzerland for the provision of synchrotron radiation beamtime on the TOMCAT beamline at the Swiss Light Source; and Charles Wellman for the acid maceration of microfossils. DW was funded by the European Commission and the Australian Research Council (FT140100321). RG is a Scientific Associate at the Natural History Museum, London and a member of the Interdisciplinary Centre for Ancient Life (UMRI). This is CCFS paper XXX. We thank Kevin Lepot and James D. Schiffbauer for their review comments that improved the quality of this paper.

\section{References}

Agic, H., MocztdlowsKa, M. \& Yin, L.-M. 2015. Affinity, life cycle, and intracellular complexity of organic-walled microfossils from the Mesoproterozoic of Shanxi, China. Journal of Paleontology, 89, 28-50.

Amos, W.B. \& White, J.G. 2003. How the confocal laser scanning microscope entered biological research. Biology of the Cell, 95, 335-342.

Arouri, K., Greenwood, P.F. \& Walter, M.R. 1999. A possible chlorophycean affinity of some
Neoproterozoic acritarchs. Organic Geochemistry, 30, $1323-1337$.

BAMBERY, K.R. 2016. Synchrotron infrared microspectroscopy of single cells at the Australian Synchrotron. Abstract presented at the 24th Australian Conference on Microscopy and Microanalysis, 31 January-4 February 2016, Melbourne, Australia.

BARghOORN, E.S. \& TYler, S.A. 1965. Microorganisms from the Gunflint Chert. Science, 147, 563-577.

Battison, L. \& Brasier, M.D. 2012. Remarkably preserved prokaryote and eukaryote microfossils within $1 \mathrm{Ga}$-old lake phosphates of the Torridon Group, NW Scotland. Precambrian Research, 196-197, 204-217.

Bernard, S., Benzerara, K. \& Beyssac, O. 2007. Exceptional preservation of fossil plant spores in highpressure metamorphic rocks. Earth and Planetary Science Letters, 262, 257-272.

Beyssac, O., Goffe, B., Chopin, C. \& Rouzard, J.N. 2002. Raman spectra of carbonaceous material in metasediments: a new geothermometer. Journal of Metamorphic Geology, 20, 859-871.

Brasier, M.D., Green, O.R., Lindsay, J.F., McLoughLin, N., Steele, A. \& Stoakes, C. 2005. Critical testing of Earth's oldest putative fossil assemblage from the $\sim 3.5 \mathrm{Ga}$ Apex chert, Chinaman Creek, Western Australia. Precambrian Research, 140, 55-102.

Brasier, M.D., Antcliffe, J., Saunders, M. \& Wacey, D. 2015. Changing the picture of Earth's earliest fossils $(3.5-1.9 \mathrm{Ga})$ with new approaches and new discoveries. Proceedings of the National Academy of Sciences of the United States of America, 112, 4859-4864.

Brasier, M.D., NoRman, D.B. ET AL. 2016. Remarkable preservation of brain tissues in an Early Cretaceous iguanodontian dinosaur. In: Brasier, A.T., McIlroy, D. \& McLoughuin, N. (eds) Earth System Evolution and Early Life: a Celebration of the Work of Martin Brasier. Geological Society, London, Special Publications, 448, http://doi.org/10.1144/SP448.3

Buseck, P.R., Bo-Jun, H. \& Miner, B. 1988. Structural order and disorder in Precambrian kerogens. Organic Geochemistry, 12, 221-234.

BUTTERFIELD, N.J. 2005. Reconstructing a complex early Neoproterozoic eukaryote, Wynniatt Formation, Arctic Canada. Lethaia, 38, 155-159.

Callow, R., Battison, L. \& Brasier, M.D. 2011. Diverse microbially induced sedimentary structures from $1 \mathrm{Ga}$ lakes of the Diabaig Formation, Torridon Group, northwest Scotland. Sedimentary Geology, 239, $117-128$.

Calvert, C.C., Brown, A. \& Brydson, R. 2005. Determination of the local chemistry of iron in inorganic and organic materials. Journal of Electron Spectroscopy and Related Phenomena, 143, 173-187.

Cavalazzi, B., Westall, F., Cady, S.L., Barbieri, R. \& Foucher, F. 2011. Potential fossil endoliths in vesicular pillow basalt, Coral Patch Seamount, eastern North Atlantic Ocean. Astrobiology, 11, 619-632.

Chen, Y., Zou, C., Mastalerz, M., Hu, S., Gasaway, C. \& TAO, X. 2015. Applications of micro-Fourier transform infrared spectroscopy (FTIR) in the geological sciences - a review. International Journal of Molecular Sciences, 16, 30223-30250. 


\section{ANALYTICAL TECHNIQUES FOR PROTEROZOIC MICROFOSSILS}

Chi, H., Xiao, Z., Fu, D. \& Lu, Z. 2006. Analysis of fluorescence from algae fossils of the Neoproterozoic Doushantuo Formation of China by confocal laser scanning microscope. Microscopy Research and Technique, 69, 253-259.

CNudde, V. \& Boone, M.N. 2013. High-resolution X-ray computed tomography in geosciences: a review of the current technology and applications. Earth-Science Reviews, 123, 1-17.

Conroy, G.C. \& Vannier, M.W. 1984. Noninvasive three-dimensional computer imaging of matrix-filled fossil skulls by high-resolution computed tomography. Science, 226, 456-458.

De Gregorio, B.T., Sharp, T.G., Flynn, G.J., Wirick, S. \& Hervig, R.L. 2009. Biogenic origin for Earth's oldest putative microfossils. Geology, 37, 631-634.

Donoghue, P.C.J., Bengtson, S. ET AL. 2006. Synchrotron X-ray tomographic microscopy of fossil embryos. Nature, 442, 680-683.

Dutta, S., Hartkopf-Froder, C., Witte, K., Brocke, R. \& MANN, U. 2013. Molecular characterization of fossil palynomorphs by transmission micro-FTIR spectroscopy: implications for hydrocarbon source evaluation. International Journal of Coal Geology, 115, 13-23.

EDWARdS, N.P., MaNNING, P.L. ET AL. 2014. Leaf metallome preserved over 50 million years. Metallomics, 6 , $774-782$.

Farquhar, J., Cliff, J. et AL. 2013. Pathways for Neoarchean pyrite formation constrained by mass-independent sulfur isotopes. Proceedings of the National Academy of Sciences of the United States of America, 110, 17638-17643.

Fenter, P., Rivers, M., Sturchio, N. \& Sutton, S. (eds) 2002. Applications of Synchrotron Radiation in LowTemperature Geochemistry and Environmental Sciences. Reviews in Mineralogy and Geochemistry, 49. Mineralogy Society of America, Washington DC.

Foucher, F. \& Westall, F. 2013. Raman imaging of metastable opal in carbonaceous microfossils of the 700-800Ma Old Draken Formation. Astrobiology, 13, 57-67.

Fries, M. \& Steele, A. 2011. Raman spectroscopy and confocal Raman imaging in mineralogy and petrography. In: Dieing, T., Hollricher, O. \& Toporski, J. (eds) Confocal Raman Microscopy. Springer Series in Optical Sciences, 158, 111-135.

GARWOOD, R.J. \& DunLOP, J. 2014. The walking dead: Blender as a tool for paleontologists with a case study on extinct arachnids. Journal of Paleontology, 88, 735-746.

Garwood, R.J. \& SutTon, M.D. 2010. X-ray microtomography of Carboniferous stem-Dictyoptera: new insights into early insects. Biology Letters, 6, 699-702.

Garwood, R.J., Ross, A., Sotty, D., Chabard, D., Charbonnier, S., Sutton, M. \& Withers, P.J. 2012. Tomographic reconstruction of neopterous Carboniferous insect nymphs. PLoS One, 7, e45779.

Grey, K. 1999. A Modified Palynological Preparation Technique for the Extraction of Large Neoproterozoic Acanthomorph Acritarchs and other Acid Insoluble Microfossils. Geological Survey of Western Australia, Record 1999/10.

Hagadorn, J.W., Xiao, S. et AL. 2006. Cellular and subcellular structure of Neoproterozoic animal embryos. Science, 314, 291-294.
Halbhuber, K.-J. \& Konig, K. 2003. Modern laser scanning microscopy in biology, biotechnology and medicine. Annals of Anatomy, 185, 1-20.

Haubitz, B., Prokop, M., Doehring, W., Ostrom, J.H. \& Wellnhofer, P. 1988. Computed tomography of Archaeopteryx. Palaeobiology, 14, 206-213.

Hickman-Lewis, K., Garwood, R., Withers, P. \& WACEY, D. 2016. X-ray microtomography as a tool for investigating the petrological context of Precambrian cellular remains. In: Brasier, A.T., McIlroy, D. \& McLoughlin, N. (eds) Earth System Evolution and Early Life: a Celebration of the Work of Martin Brasier. Geological Society, London, Special Publications, 448, http://doi.org/10.1144/SP448.11

HofmanN, H.J. 1976. Precambrian microflora, Belcher Islands, Canada: significance and systematics. Journal of Palaeontology, 50, 1040-1073.

House, C.H., Schopf, J.W., McKeegan, K.D., Coath, C.D., Harrison, T.M. \& Stetter, K.O. 2000. Carbon isotopic composition of individual Precambrian microfossils. Geology, 28, 707-710.

Huldtgren, T., Cunningham, J.A., Yin, C., Stampanoni, M., Marone, F., Donoghue, P.C.J. \& BengtSON, S. 2011. Fossilized nuclei and germination structures identify Ediacaran 'animal embryos' as encysting protists. Science, 334, 1696-1699.

Igisu, M., Ueno, Y., Shimojima, M., Nakashima, S., Awramik, S.M., Ohta, H. \& Maruyama, S. 2009. Micro-FTIR spectroscopic signatures of bacterial lipids in Proterozoic microfossils. Precambrian Research, 173, 19-26.

IgISU, M., TAKAI, K. ET AL. 2012. Domain-level identification and quantification of relative prokaryote cell abundance in microbial communities by micro-FTIR spectroscopy. Environmental Microbiology Reports, 4, 42-49.

IRELAND, T.R. 1995. Ion microprobe mass spectrometry: techniques and applications in cosmochemistry, geochemistry, and geochronology. In: HyMAN, M. \& Rowe, M. (eds) Advances in Analytical Geochemistry. JAI Press, Greenwich, CT, 1-118.

Javaux, E.J., Knoll, A.H. \& Walter, M.R. 2004. TEM evidence for eukaryotic diversity in mid-Proterozoic oceans. Geobiology, 2, 121-132.

Jehlicka, J., Urban, O. \& PoKorny, J. 2003. Raman spectroscopy of carbon and solid bitumens in sedimentary and metamorphic rocks. Spectrochimica Acta A, 59, 2341-2352.

KaK, A.C. \& Slaney, M. 2001. Principles of Computerized Tomographic Imaging. Society of Industrial and Applied Mathematics, Philadelphia.

Kempe, A., Wirth, R., Altermann, W., Stark, R.W. SCHOPF, J.W. \& HeCKL, W.M. 2005. Focussed ion beam preparation and in situ nanoscopic study of Precambrian acritarchs. Precambrian Research, 140, 36-54.

KILBURN, M.R. \& WACEY, D. 2015. NanoSIMS as an analytical tool in the geosciences. In: GrICE, K. (ed.) Principles and Practice of Analytical Techniques in Geosciences. Royal Society of Chemistry, Cambridge, $1-34$.

KNoll, A.H. 1994. Proterozoic and early Cambrian protists: evidence for accelerating evolutionary tempo. Proceedings of the National Academy of Sciences of the United States of America, 91, 6743-6750. 


\section{WACEY ET AL.}

KNolL, A.H. 2015. Life on a Young Planet: the First Three Billion Years of Evolution on Earth. 2nd edn. Princeton University Press, Princeton, NJ.

Knoll, A.H., Javaux, E.J., Hewitt, D. \& Cohen, P. 2006. Eukaryotic organisms in Proterozoic oceans. Philosophical Transactions of the Royal Society B, 361, 1023-1038.

Lawrence, J.R., Swerhone, G.D.W., Leppard, G.G., Araki, T., Zhang, X., West, M.M. \& HitchCock, A.P. 2003. Scanning transmission X-ray, laser scanning, and transmission electron microscopy mapping of the exoploymeric matrix of microbial biofilms. Applied and Environmental Microbiology, 69, $5543-5554$.

Lemelle, L., Labrot, P., Salome, M., Simionovici, A., Viso, M. \& Westall, F. 2008. In situ imaging of organic sulfur in 700-800 My-old Neoproterozoic microfossils using X-ray spectromicroscopy at the $\mathrm{S}$ K-edge. Organic Geochemistry, 39, 188-202.

Limaye, A. 2012. Drishti: a volume exploration an presentation tool. In: SPIE Optical Engineering+ Applications. International Society for Optics and Photonics, 85060X-85060X.

Marshall, C.P. \& Olcott Marshall, A. 2013. Raman hyperspectral imaging of microfossils: potential pitfalls. Astrobiology, 13, 920-931.

Marshall, C.P., Javaux, E.J., Knoll, A.H. \& Walter, M.R. 2005. Combined micro-Fourier transform infrared (FTIR) spectroscopy and micro-Raman spectroscopy of Proterozoic acritarchs: a new approach to palaeobiology. Precambrian Research, 138, 208-224.

Marshall, C.P., Emry, J.R. \& Olcott Marshall, A. 2011. Haematite pseudomicrofossils present in the 3.5-billion-year-old Apex Chert. Nature Geoscience, 4, 240-243.

Mayo, D.W., Miller, F.A. \& Hannah, R.W. (eds) 2004. Course Notes on the Interpretation of Infrared and Raman Spectra. Wiley Online Library, Hoboken, NJ.

McCollom, T.M. \& Seewald, J.S. 2006. Carbon isotope composition of organic compounds produced by abiotic synthesis under hydrothermal conditions. Earth and Planetary Science Letters, 243, 64-84.

MoczydlowsKa, M. \& Willman, S. 2009. Ultrastructure of cell walls in ancient microfossils as a proxy to their biological affinities. Precambrian Research, 173, $27-38$.

Moreau, J.W. \& Sharp, T.G. 2004. A transmission electron microscopy study of silica and kerogen biosignatures in $\sim 1.9 \mathrm{Ga}$ Gunflint microfossils. Astrobiology, 4, 196-210.

Oehler, D.Z. 1977. Pyrenoid-like structures in Late Precambrian algae from the Bitter Springs Formation. Journal of Paleontology, 51, 885-901.

Oehler, D.Z., Robert, F., Mostefaoui, S., Meibom, A., Selo, M. \& McKay, D.S. 2006. Chemical mapping of Proterozoic organic matter at submicron spatial resolution. Astrobiology, 6, 838-850.

Oehler, D.Z., Robert, F. et aL. 2009. NanoSIMS: insights to biogenicity and syngeneity of Archaean carbonaceous structures. Precambrian Research, 173, $70-78$.

PaCton, M., Fiet, N. \& Gorin, G. 2007. Bacterial activity and preservation of sedimentary organic matter: the role of exopolymeric substances. Geomicrobiology Journal, 24, 571-581.

PANG, K., TANG, Q. ET AL. 2013. The nature and origin of nucleus-like intracellular inclusions in Paleoproterozoic eukaryote microfossils. Geobiology, 11, 499-510.

Pasteris, J.D. \& Wopenka, B. 2003. Necessary, but not sufficient: Raman identification of disordered carbon as a signature of ancient life. Astrobiology, 3, 727-738.

Qu, Y., Engdahl, A., Zhu, S., Vajda, V. \& McLoughLIN, N. 2015. Ultrastructural heterogeneity of carbonaceous material in ancient cherts: investigating biosignature origin and preservation. Astrobiology, 15, 825-842.

RAHMAN, I.A. \& ZAMORA, S. 2009. The oldest cinctan carpoid (stem-group Echinodermata), and the evolution of the water vascular system. Zoological Journal of the Linnean Society, 157, 420-432.

Rasmussen, B. 2000. Filamentous microfossils in a 3,235-million-year-old volcanogenic massive sulphide deposit. Nature, 405, 676-679.

Rasmussen, B., Fletcher, I.R., Brocks, J.J. \& Kilburn, M.R. 2008. Reassessing the first appearance of eukaryotes and cyanobacteria. Nature, 455, 1101-1104.

Rasmussen, B., Blake, T.S., Fletcher, I.R. \& Kilburn, M.R. 2009. Evidence for microbial life in synsedimentary cavities from $2.75 \mathrm{Ga}$ terrestrial environments. Geology, 37, 423-426.

Rowe, T.B., Colbert, M., Ketcham, R.A., Maisano, J. \& Owen, P. 2001. High-resolution X-ray computed tomography in vertebrate morphology. Journal of Morphology, 248, 277-278.

SChiffBAuER, J.D. \& XiaO, S. 2009. Novel application of focused ion beam electron microscopy (FIB-EM) in preparation and analysis of microfossil ultrastructures: a new view of complexity in early eukaryotic organisms. Palaios, 24, 616-626.

Schiffbauer, J.D., Xiao, S., Sharma, K.S. \& Wang, G. 2012. The origin of intracellular structures in Ediacaran metazoan embryos. Geology, 40, 223-226.

Schopf, J.W. \& Kudryavtsev, A.B. 2005. Threedimensional Raman imagery of Precambrian microscopic organisms. Geobiology, 3, 1-12.

Schopf, J.W. \& KudRyavtsev, A.B. 2009. Confocal laser scanning microscopy and Raman imaging of ancient microscopic fossils. Precambrian Research, $\mathbf{1 7 3}$ $39-49$.

Schopf, J.W., Kudryavtsev, A.B., Agresti, D.G., CzaJA, A.D. \& Wdowiak, T.J. 2005. Raman imagery: a new approach to assess the geochemical maturity and biogenicity of permineralized Precambrian fossils. Astrobiology, 5, 333-371.

Schopf, J.W., Tripathi, A.B. \& Kudryavtsev, A.B. 2006. Three-dimensional confocal optical imagery of Precambrian microscopic organisms. Astrobiology, 6 , $1-16$.

Schopf, J.W., Tewari, V.C. \& Kudryavtsev, A.B. 2008 Discovery of a new chert-permineralized microbiota in the Proterozoic Buxa Formation of the Ranjit Window, Sikkim, northeast India, and its astrobiological implications. Astrobiology, 8, 735-746.

She, Z., Strother, P. ET AL. 2013. Terminal Proterozoic cyanobacterial blooms and phosphogenesis documented by the Doushantuo granular phosphorites 


\section{ANALYTICAL TECHNIQUES FOR PROTEROZOIC MICROFOSSILS}

I: in situ micro-analysis of textures and composition. Precambrian Research, 235, 20-35.

Spencer, A.R.T., Hilton, J. \& Sutton, M.D. 2013. Combined methodologies for three-dimensional reconstruction of fossil plants preserved in siderite nodules: Stephanospermum braidwoodensis nov sp (Medullosales) from the Mazon Creek lagerstatte. Review of Palaeobotany and Palynology, 188, 1-17.

Stern, R.A., Bodorkos, S., Kamo, S.L., Hickman, A.H. \& Corfu, F. 2009. Measurement of SIMS instrumental mass fractionation of $\mathrm{Pb}$ isotopes during zircon dating. Geostandards and Geoanalytical Research, 33, $145-168$.

Stewart, A.D. \& Parker, A. 1979. Palaeosalinity and environmental interpretation of red beds from the Late Precambrian ('Torridonian') of Scotland. Sedimentary Geology, 22, 229-241.

Streng, M., Butler, A.D., Peel, J.S., Garwood, R.J. \& CARon, J. 2016. A new family of Cambrian rhynchonelliformean brachiopods (Order Naukatida) with an aberrant coral-like morphology. Palaeontology, 59, 269-293.

Strother, P.K. \& Wellman, C.H. 2015. Palaeoecology of a billion-year-old non-marine cyanobacterium from the Torridon Group and Nonsuch Formation. Palaeontology, http://doi.org/10.1111/pala.12212

Strother, P.K., Battison, L., Brasier, M.D. \& WellMAN, C.H. 2011. Earth's earliest non-marine eukaryotes. Nature, 473, 505-509.

SutTon, M.D. 2008. Tomographic techniques for the study of exceptionally preserved fossils. Proceedings of the Royal Society B, 275, 1587-1593.

Sutton, M.D., Briggs, D.E.G., Siveter, D.J. \& Siveter, D.J. 2001. An exceptionally preserved vermiform mollusk from the Silurian of England. Nature, 410, 461-463.

Sutton, M.D., Garwood, R.J., Siveter, D.J. \& Siveter, D.J. 2012. SPIERS and VAXML: a software toolkit for tomographic visualization and a format for virtual specimen interchange. Palaeontologica Electronica, $15,5 \mathrm{~T}$

SutTon, M.D., Rahman, I.A. \& GaRwOOD, R.J. 2014. Techniques for Virtual Palaeontology. WileyBlackwell, Oxford.

Templeton, A. \& Knowles, E. 2009. Microbial transformations of minerals and metals: recent advances in geomicrobiology derived from synchrotron-based $\mathrm{X}$-ray spectroscopy and X-ray microscopy. Annual Reviews in Earth and Planetary Science, 37, 367-391.

Thomen, A., Robert, F. \& Remusat, L. 2014. Determination of the nitrogen abundance in organic materials by NanoSIMS quantitative imaging. Journal of Analytical Atomic Spectrometry, 29, 512-519.

Tice, M.M., Bostick, B.C. \& Lowe, D.R. 2004. Thermal history of the 3.5-3.2 Ga Onverwacht and Fig Tree Groups, Barberton greenstone belt, South Africa, inferred by Raman microspectroscopy of carbonaceous material. Geology, 32, 37-40.

Vandenbroucke, M. \& Largeau, C. 2007. Kerogen origin, evolution and structure. Organic Geochemistry, 38, $719-833$.

WACEY, D. 2014. In situ morphologic, elemental and isotopic analysis of Archean life. In: DILEK, Y. \&
Furnes, H. (eds) Evolution of Archean Crust and Early Life. Modern Approaches in Solid Earth Sciences, 7. Springer, Berlin, 351-365.

Wacey, D., Kilburn, M.R., Saunders, M., Cliff, J. \& BRASIER, M.D. 2011. Microfossils of sulfur metabolizing cells in $\sim 3.4$ billion year old rocks of Western Australia. Nature Geoscience, 4, 698-702.

Wacey, D., Menon, S. ET AL. 2012. Taphonomy of very ancient microfossils from the $\sim 3400 \mathrm{Ma}$ Strelley Pool Formation and $\sim 1900$ Ma Gunflint Formation: new insights using focused ion beam. Precambrian Research, 220-221, 234-250.

Wacey, D., McLoughlin, N. ET AL. 2013. Nano-scale analysis reveals differential heterotrophic consumption in the $\sim 1.9 \mathrm{Ga}$ Gunflint Chert. Proceedings of the National Academy of Sciences of the United States of America, 110, 8020-8024.

WACEY, D., SAUnders, M. ET AL. 2014. Enhanced cellular preservation by clay minerals in 1 billion-year-old lakes. Nature Scientific Reports, 4, 5841, http://doi. org/10.1038/srep05841

WACEY, D., Brasier, M. ET AL. 2016. Contrasting microfossil preservation and lake chemistries within the 1200-1000 Ma Torridonian Supergroup of NW Scotland. In: Brasier, A.T., McIlroy, D. \& McLoughLIN, N. (eds) Earth System Evolution and Early Life: a Celebration of the Work of Martin Brasier. Geological Society, London, Special Publications, 448, http://doi.org/10.1144/SP448.6

Westall, F., de Ronde, C.E.J., Southam, G., Grassineau, N., Colas, M., Cockell, C. \& Lammer, H. 2006. Implications of a $3.472-3.333$ Gyr-old subaerial microbial mat from the Barberton greenstone belt, South Africa for the UV environmental conditions on the early Earth. Philosophical Transactions of the Royal Society B, 361, 1857-1875.

Williams, D.B. \& CARTER, C.B. 2009. Transmission Electron Microscopy: a Textbook for Materials Science. 2nd edn. Springer Science and Business Media, New York.

Williford, K.H., Ushikubo, T., Schopf, J.W., Lepot, K., Kitajima, K. \& Valley, J.W. 2013. Preservation and detection of microstructural and taxonomic correlations in the carbon isotopic compositions of individual Precambrian microfossils. Geochimica et Cosmochimica Acta, 104, 165-182.

WIRTH, R. 2009. Focused ion beam (FIB) combined with SEM and TEM: advanced analytical tools for studies of chemical composition, microstructure and crystal structure in geomaterials on a nanometre scale. Chemical Geology, 261, 217-229.

WOPENKA, B. \& PASTERIS, J.D. 1993. Structural characterization of kerogens to granulite-facies graphite: applicability of Raman microprobe spectroscopy. American Mineralogist, 78, 533-557.

YIN, L. \& LI, Z. 1978. Precambrian microfloras of southwest China with reference to their stratigraphic significance. Memoir Nanjing Institute of Geology and Palaeontology, Academia Sinica, 10, 41-108.

Young, R.J. \& Moore, M.V. 2005. Dual-beam (FIBSEM) systems. In: Gianuzzi, L.A. \& Stevie, F.A. (eds) Introduction to Focused Ion Beams. Instrumentation, Theory, Techniques and Practice. Springer Science and Business Media, New York, 246-268. 
